THE ROLE OF THE EUROPEAN COURT OF HUMAN RIGHTS IN ENSURING THE RIGHT TO A FAIR TRIAL WITH THE REPUBLIC OF LATVIA AND REPUBLIC OF FINLAND AS AN EXAMPLE

Summary of Doctoral Thesis for obtaining the degree of the Doctor of Law Speciality - Law Subfield - International Law 


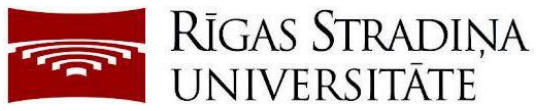

Vladimir Jilkine

\section{THE ROLE OF THE EUROPEAN COURT OF HUMAN RIGHTS IN ENSURING THE RIGHT TO A FAIR TRIAL WITH THE REPUBLIC OF LATVIA AND REPUBLIC OF FINLAND AS AN EXAMPLE}

Summary of the Doctoral Thesis for obtaining the degree of the Doctor of Law

Speciality - Law

Subfield - International Law

Riga, 2016 
The Doctoral Thesis was carried out at Rīga Stradiņš University

Scientific supervisor:

Dr. iur., Professor Vitolds Zahars,

Rīga Stradiņš University, Latvia

Official reviewers:

Dr. iur., Professor Aivars Endzin̦š,

Turība University, Latvia

Dr. iur., Dr. psych., Professor Viktoras Justickas,

Mykolas Romeris University, Lithuania

Dr. iur., Associate Professor Jānis Grasis,

Rīga Stradiņš University, Latvia

Defence of the Doctoral Thesis will take place at the public session of the Doctoral Council of Legal Sciences on 1 November 2016 at 10.00 in Hippocrates Lecture Theatre, Dzirciema Street 16, Rīga Stradinš University.

The Doctoral Thesis is available at RSU Library and RSU homepage: www.rsu.lv

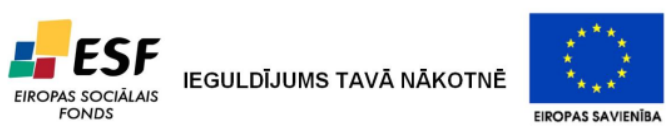

The thesis was elaborated with the financial support under the ESF project of "Support

for the Acquisition of Doctoral Study Programmes and Scientific Degree at Rīga

Stradiṇš University", agreement No. 2009/0147/1DP/1.1.2.1.2./09/IPIA/VIAA/009.

Secretary of the Promotion Council:

Dr. iur., Professor Sandra Kaija 


\section{CONTENTS}

General description of the doctoral thesis

4

1. LEGAL MEANING OF THE CONSTITUTION OF THE REPUBLIC OF LATVIA AND THE REPUBLIC OF FINLAND AS THE DECISIONS OF THE EUROPEAN COURT OF HUMAN RIGHTS FOR THE NATIONAL LAW PROCEEDING

Brief summary of Chapter 1

2. RIGHT TO A FAIR TRIAL BY A COMPETENT, INDEPENDENT AND IMPARTIAL TRIBUNAL ESTABLISHED BY LAW

Brief summary of Chapter 2

3. REVIEW OF LAWSUITS IN THE SUPREME COURT OF THE REPUBLIC OF LATVIA AND THE REPUBLIC OF FINLAND

Brief summary of Chapter 3

4. EQUALITY OF PARTIES AND FAIR TRIAL GUARANTEES FROM THE POSITION OF EUROPEAN COURT OF HUMAN RIGTHS .34

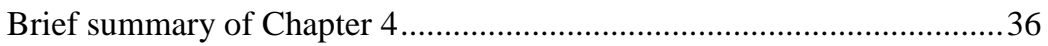

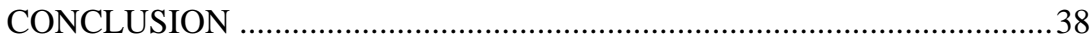

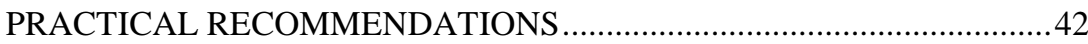

LIST OF REFERENCES AND OTHER SOURCES …..............................48

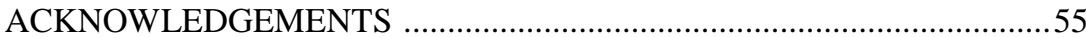




\section{GENERAL DISCRIPTION OF THE DOCTORAL THESIS}

This research is the first comparative study on a detailed investigation of the values of the European Convention and the role of the European Court of Human Rights to ensure the right to a fair trial in the Constitutional Court and the Supreme Court of the Republic of Latvia and the Supreme Court of the Republic of Finland, including the consideration of claims that have come into enforceable decisions of national courts. The basis for the review of the case in court is, in particular, the establishment of the European Court of Human Rights violations of the provisions for the Protection of Human Rights and Fundamental Freedoms and the attached Protocols.

The author has studied and analyzed the materials of the Constitutional Court's decisions and the three departments of the Supreme Court of the Republic of Latvia, as well as the decisions of the Supreme Court and the Supreme Administrative Court of the Republic of Finland between 2010 and 2015, including the claims review for quashing of the final criminal cases on the basis of ECHR decisions made on the recognition of violations of articles of the Convention and its protocols. According to the questionnaire, developed by the author, a sociological survey was conducted in the Republic of Latvia and thr Republic of Finland. This paper used and analyzed decisions, published on the official websites of the European Court of Human Rights, the Constitutional Court, Supreme Court and the Prosecutor's Office of the Republic of Latvia, reports the Government of the Republic of Latvia on the implementation of ECHR decisions, as well as data obtained from the Supreme Court and Supreme Administrative Court of Republic of Finland, related to the implementation of the ECHR case law, showing patterns and marked deviations from the implementation of ECHR decisions in an event of a conflict between international law and the Constitution of the state.

Relevance of the paper. Ensuring provision of human rights is a basic principle of a democratic state, as well as one of the elements of the rule of law. The State has the responsibility to provide the human rights and freedoms, as well as to eliminate any potential violations. The preamble to the Convention for the Protection of Human Rights and Fundamental Freedoms (ECHR) states that respect for human rights and fundamental freedoms can best be accomplished by an effective political democracy. 
This Doctoral thesis for the first time considered the comparison between adjudication ruling of the European Court of Human Rights in Republic of Latvia and Republic of Finland, with the analysis of the review of cases through national judicial procedure based on the recent findings made by ECHR of violations of the Convention and its protocols.

The author conducted a comparative analysis of international and national legislations of the Latvian Republic and the Republic of Finland, judicial practice, study of findings and the basis of decision by the Constitutional Court as well as the three Departments of the Supreme Court of the Republic of Latvia, the Supreme Court and the Supreme Administrative Court of the Republic of Finland, author proposes the following research questions for consideration:

1. How to apply the European Convention and the international standards of human rights in the national court system to an extent that does not lead to decrease or limitation of fundamental rights included in the Constitution? How to keep the constitutional sovereignty of the state and improve the protection of the rights and freedoms of man and citizen guaranteed by the Constitution and the European Convention?

2. How to use the provisions of the Convention to ensure the right to a fair trial in Latvia and Finland, which is independent of politics and based on the rule of the Constitution and the application of international law to the extent that does not lead to decrease or limitation of fundamental rights included in the Constitution? How to optimize a fair trial in the lawsuit to quash the previously made decisions of the national court on the basis of newly discovered facts about the recognition of a violation of the ECHR and its Protocols?

3. What is the priority in addressing judicial errors identified by the ECHR - ECHR decision or the Constitution of the Republic of Latvia and the Republic of Finland and whether the practice of courts in Latvia and Finland corresponds to the requirements set by the ECHR on the right to a fair trial?

4. Can judgments delivered by ECHR on the appeal be enforced against Latvia and Finland, if it leads to a contradiction with the Constitution, and calls into question the supremacy of the Constitution, which has in the legal system a higher legal force in relation to any legal acts? 


\section{Scientific novelty of the Doctoral Thesis is:}

1. Doctoral thesis is a study on the theoretical understanding of the role of the ECHR, the ECHR case - law in the system of law in these countries and the case-law of the Constitutional Court and the three departments of the Supreme Court of the Republic of Latvia, the Supreme Court and the Supreme Administrative Court of Finland, the consideration of claims for cancellation of decisions which entered into force of judgments by national courts after the ECHR identifies a violation of articles of the Convention or its' Protocols.

2. From the analysis of decisions of the Constitutional Court of the Republic of Latvia and the Supreme Court of the Republic of Finland, concluded that the priority of the Constitution of the resolution of the constitutional and legal conflicts that may arise in connection with the interpretation of the Convention for the Protection of Human Rights and Fundamental Freedoms.

3. In a study presented to the comparative analysis of the Constitution of the European countries, Russia and the USA, on the basis of which the author presented the position that the protection of national security and human rights of the Constitution states take precedence over international law, which only complement its basic principles.

4. To conduct a comparative study of the problem of compliance enforcement practice of Latvia and Finland with European standards of justice analysed the jurisprudence of the European Court of Human Rights and its application in the proceedings of these countries.

5. Scientific novelty of the study is a research into the influence of European Convention on Human Rights and the European Court of Human Rights on the national court proceedings in the Republic of Latvia and the Republic of Finland, for reviewing claims in the Supreme Court of the Republic of Latvia and the Republic of Finland, for quashing of prior decisions based on the violations of the Convention identified by the ECHR.

6. The Doctoral thesis is written for the first time not only with the analysis of the decisions of the ECHR, but also supported by the analysis of other adjoining regulations, statistics and a large amount of literature by Latvian and Finnish authors previously untouched in a legal science in Finland and Latvia, as well as interviews with the Judges for the European Court of Human Rights and with the Judges and former Judges for the Constitutional Courts of the Republic of Latvia. 
The scope and structure of Doctoral Thesis. The structure is defined by the object and subject, with the targets and missions, consisting of four chapters, which include eighteen paragraphs, conclusions, appendices and bibliography for the sources as well as the surveys.

The purpose of the study is to determine the values of the ECHR for the national judicial decisions in Latvia and Finland to ensure the right to a fair trial in the context of the provisions of the European Convention and the ECHR and the most effective mechanisms to enforce the ECHR decision in the national court proceedings.

Location of studies: Latvia and Finland.

The theoretical basis of the research also include scientific works, which deal with the theory of international law, by Latvian, Finnish and other foreign authors - former chairman of the Constitutional Court of the Republic of Latvia Aivars Endziņš, Gunārs Kūtris, Deputy Chairman of the Constitutional Court of the Republic of Latvia Uldis Kinis, former Judges of the Constitutional Court Anita Ušacka and Juris Jelāgins, former Judges of ECHR from Latvia and Finland Egils Levits, Ineta Ziemele, Matti Pellonpää and Päivi Hirvelä, as well as new Judges of ECHR Martins Mits and Pauliine Koskelo, as well as legal scholars from the Republic of Latvia and the Republic of Finland: Osvalds Joksts, Tālavs Jundzis, Jānis Grasis, Uldis Krastiņš, Kalvis Torgāns, Andrejs Vilks, Sandra Kaija, Aulis Aarnio, Markku Fredman, Martin Scheinin, Pasi Pölönen, Antti Tapanila and legal scholars from Russia: Kashepov V.P., Kovler A. I., Osminin B. I. and Rudnev V. I.

General scientific and special judicial methods were employed in the process of doctoral thesis research.

The historical method was used to study the origin and development of human rights institutions at various evolution stages of the state and society, including the right to a fair trial.

The comparative method was used in the work analysis of various authors and rights experts on the role of the European Court of Human Rights and the courts of all instances of nation-states in ensuring the right to a fair trial in accordance with the Constitution and international obligations of those States. This method clarified common and distinctive features in the jurisprudence of the Republic of Latvia and the Republic of Finland.

Formal-logical method was used in clarifying certain relationships in the jurisprudence of the Republic of Finland and the Republic of Latvia in the 
context of the right to a fair trial in court and formulating the author's position on controversial legal issues.

Induction method was used in the processing of empirical material, with its application the author has compiled and thoroughly examined the specific facts of the judicial practice of the Republic of Finland and the Republic of Latvia, which allowed him to make logical generalizations, which formed the basis of the author's conclusions and proposals in the field of rulemaking.

Using the method of deduction, the author was able to comprehend and understand the logic and the basis of individual decisions of the European Court of Human Rights as well as courts at all levels in both the Republic of Latvia and the Republic of Finland.

To illustrate the need for and feasibility of certain provisions of law and assessment of the validity of decisions by the courts at all levels the authors used theoretical modeling method.

The work is based on 490 sources.

The Doctoral thesis comprises of an introduction, four main chapters, conclusions and suggestions, as well as a list of used sources.

The study showed that the greatest number of violations by the national courts is related to the derogation from Article 6 of the Convention. Miscarriage of justice in sentencing by national courts and the ever-increasing number of cases in the higher courts require amendment of the national legislation and the reform of the judicial system in accordance with the standards of the Council of Europe legislation.

The study discussed in detail examples of the application by the Constitutional Court of the Republic of Latvia, the Supreme Courts of both the Republic of Latvia and the Republic of Finland of the judicial precedents of the ECHR when considering similar cases by the national courts of those countries.

The Doctoral thesis is a study on the theoretical understanding of the role of the European Convention and ECHR case law on the system of law and the case-law of the Supreme Court of the Republic of Latvia and the Supreme Court of Republic of Finland.

The practical significance of the thesis is that formulated reasoned proposals (de lege ferenda) can be taken into account in the improvement of national legislation and law enforcement to bring them into compliance with international legal provisions, which are reflected in the European Convention on Human Rights and fundamental freedoms. 
Results of the research. Testing of the theme, main points and conclusions, reflected in the presentations and discussions at the 9 scientific and academic conferences and 21 publications of the author in the Europe, Russia and United States, which has set forth the main content of heading for the promotion thesis, as well as in legal journals of Europe and USA, including Latvia and Russia, in conjunction with lecturing at the MBA Faculty of Law and more than 10 year practice of Law in Finland, compiling 5 appeals and complains to the ECHR, drafting and conducting civil cases in local courts with foreign energy companies, as well as multiple quarums and court cases which included international companies and private clients.

This Doctoral thesis made use of materials from the cases made by the author for the claims and appeals brought forward for ECHR review as well as case-work of different stages of Finnish Courts.

The main aspects of the findings and deductions will help develop some of the theory of international law and will expand the concept of international and constitutional law. Acquired results can serve as a basis for further research by the author.

\section{List of presentatons at scientific conferences}

1. $2^{\text {nd }}$ International Scientific and practical conference proceedings. "The Transformation Process of Law, the Regional Economy and Economic Policy: Topical Economic, Political and Legal Issues”. 10.12.2013. BSA, Riga.

2. IV International young researchers and students' scientific and practical conference "Time of Challenges and Possibilities: Problems, development and perspectives". 15-16.5.2014.

3. $3^{\text {nd }}$ International Scientific Conference. "Transformation Process in Law, Regional Economy and Economic Policies: Topical Economic, Political and Legal Issues". BSA. Riga. 12 December 2014.

4. International Practical Conference in RSU. Topical Problems of Security Reinforcement: Political, Social, Legal Aspects. Riga, April 23, 2015.

5. International conference in BSA. Modernization of private contemporary trends. Privāttiesību modernizācijas mūsdienu tendences. Riga. 23-24 April 2015.

6. V International young researchers and students scientific and practical conference "Transformation of regional Economies: sustainable development and Competitiveness". BSA, Riga. 14-15 May 2015. 
7. Scientific Conference "New Challenges of Today's Society in Strengthening Security: State of Play and Future Perspectives". Riga Stradins University. 20 April 2016.

8. Scientific Conference "Crime Prevention: Current Trends and Processes”. BSA, Riga, 22 April 2016, in absentia.

9. Conference in Ryazan State University of S. A. Esenin. "The rights and freedoms of man and citizen: theoretical aspects and legal practice". 28 April 2016, in absentia.

\section{Published Articles}

1. Применение статьи 6 Конвенции о защите прав человека и основных свобод в уголовном процессе в Финляндии при расследовании дел о банкротстве и взыскании долга. Published: The Baltic Journal of Law. 2013 Nr. 4, ISSN 1691-0702. C. 62-72.

2. Применение статьи 6 Конвенции о защите прав человека и основных свобод в уголовном процессе в Финляндии. Published: The transformation process of law, the regional economy and economic policy: the relevant economic and political and legal issues. 2nd International scientific and practical conference proceedings. ISBN 978-9984-47-096-2. C. 61-65.

3. Практика применения Постановлений ЕСПЧ в Верховном Суде Финляндии. Published: IV International young reserchers and students' scientific and practical conference "Time of challenges and possibilities: Problems, development and perspectives”. BSA. ISBN 978-9984-47-091-7. C. $116-123$.

4. The Role of European Court of Human Rights to a Fair Trial in Finnish Supreme Court (Poster presentation). International Multidisciplinary Scientific Conferences on Social Sciences and Arts - SGEM2014 01.09.201410.09.2014. Bulgaria. Published: International Multidisciplinary Scientific Conferences on Social Sciences and Arts - SGEM 2014. Bulgaria, Volume 1. ISSN 2367-5659, ISBN 978-619-7105-25-4, pp. 901-908.

5. The Implementation of the Ne bis in idem-principle in the Supreme Court of Finland. International Multidisciplinary Scientific Conferences on Social Sciences and Arts - SGEM2014 01.09.2014-10.09.2014. Bulgaria. Published: International Multidisciplinary Scientific Conferences on Social Sciences and Arts - SGEM 2014, Volume 1. ISSN 2367-5659, ISBN 978-6197105-25-4, pp. 861-867. 
6. Право на уважение частной жизни и прослушивание телефонов в международном праве на примере судопроизводства Финляндии. Published: The Baltic Journal of Law 2015 Nr. 4, ISSN 1691-0702. C. 74-86.

7. Прецеденты Европейского суда по правам человека и реализация принципа презумпции невиновности в судопроизводстве Финляндии. Тhe Baltic Journal of Law 2015 Nr. 3, ISSN 1691-0702. C. 23-35.

8. The right to free assistance of an interpreter and /or translator based on the example of Finland. $15^{\text {th }}$ International Academic Conference. Rome, 14 April 2015 - 17 April 2015. Published: Scientific journals Procedia Economics and Finance, ISBN 978-80-87927-08-3, IISES, pp. 487-500.

9. History of Finnish Legislation and its Continuous Evolution under the Influence of Judgements by the European Court of Human Rights. 23 April 2015. International conference on security reinforcement to be held at RSU. ISBN 978-9984-793-72-6, pp.78-79.

10. Implementation of the presumption of innocence principle in European Court of Human Rights and legal proceedings of Finland. $18^{\text {th }}$ International Academic Conference. London . 25 August 2015 - 28 August 2015. Published: Scientific journals Procedia Economics and Finance, December 2015, pp. 336-350.

11. Practices of case proceedings by the Supreme Court of Finland, suspect's right to defence by means of legal assistance. $17^{\text {th }}$ International Academic Conference. Vienna, June 21-24, 2015. Published: Scientific journals Procedia Economics and Finance, IISES, pp. 185-199.

12. Защита прав человека Конституционным судом Латвийской Республики. Published: V International young researchers and students scientific and practical conference "Transformation of regional Economies: sustainable development and Competitiveness". 15 May 2015. BSA, Riga. C. $215-227$.

13. Перспективы и пути решения проблемы соблюдения права на тайну корреспонденции в контексте борьбы с преступностью в Финляндии. Published: The Journal “Juridical science” 2015 №3, ISSN 22205500. C. 92-97.

14. The fight against cyber-crime in the context of compliance with the right to protection against arbitrary or unlawful interference with privacy, family, home or correspondence based on an example of Finland. $21^{\text {th }}$ International Academic Conference, Miami, USA. 09 February 2016. ISBN 978-80-879927-19-9, IISES, pp. 96-108. 
15. Co-authored with Vitolds Zahars. Consideration of claims cancellation of decisions by national court that have entered into force by the Supreme court of Finland. Published: Administratīvā un Kriminālā Justīcija. Nr. 4/2015, pp. 3-13.

16. The implementation of international legal standards in the revision of the judgements that are in force by Supreme Court of Finland. Electronic Journal Socrates. ISSN 2256-0548 RSU. 2015 . No. 3, pp. 54-65.

17. Comparative analysis of casework by the Supreme Court of the Republic of Latvia and the Supreme Court of the Republic of Finland. Administratīvā un Kriminālā Justīcija. Article accepted for publication.

18. Priority of Constitution in the national legal system and position of international treaties in sources system of national law. Administratīivā un Kriminālā Justīcija Nr. 1, 2016. Article accepted for publication.

19. Роль и правовое значение Конституции Финляндской Республики и Латвийской Республики и решений Европейского Суда по правам человека в национальном судопроизводстве. Сборник научных трудов по материалам международного научно-практического круглого стола. Рязань. ISBN 978-5-88006-934-7, издательство “Концепция". 10.12.2015. С.100-104.

20. Роль Конституционного суда Латвийской Республики в эффективной защите прав человека. Журнал “Юридическая гносеология”. Научный журнал. 2016 №1. www.jur-gnosis.ru. C. 26-34.

21. Position of the European Court on the implementation of decisions by national courts which are in legal force. Socrates. ISSN 2256-0548 RSU Elektroniskais juridisko zinātnisko rakstu žurnāls. Article accepted for publication. 


\section{LEGAL MEANING OF THE CONSTITUTION OF THE REPUBLIC OF LATVIA AND THE REPUBLIC OF FINLAND AS THE DECISIONS OF THE EUROPEAN COURT OF HUMAN RIGHTS FOR THE NATIONAL LAW PROCEEDINGS}

The author notes that nearly 100 years ago, when developing and discussing the draft of the Constitution, the members of the Constituent Assembly repeatedly referred to the experience of democratic states of that time, thus confirming the organic link of the state system being created in Latvia with that of other progressive states. A similar approach was used by the deputies of the Supreme Council of the Republic of Latvia in restoring the Latvian state de facto and it's Constitution.

From the analysis of the practice of the Constitutional Court and that of ECHR follows, that the principle of justice as a guarantee of the constitutional human and civil rights to judicial protection includes the following constituent elements: the guarantee of access to justice, the guarantee of personal presence at the trial, the guarantee against self-incrimination, the equality and competitiveness of the parties, the guarantee of receiving a reasoned judgement.

It should be noted, the analysis of legal literature shows that the lawyers' opinions relating to the priority of the Constitution over the international law and the prejudication of ECHR tend to differ.

Ineta Ziemele confirmed again the binding authority of the European Convention for Latvia: "The Latvian system of courts is characterised by openness to the binding norms and principles of international law. The Court has always interpreted Chapter 8 of the Satversme in close connection with Latvia's international commitments in the field of human rights, in particular, by taking into consideration the case law of ECHR and the fact that the interpretation of the European Convention for the Protection of Fundamental Human Rights and Freedoms provided by ECHR is binding upon Latvia."1

Former Judge of ECHR Egils Levits (1995-2004) also noted that the Convention treaties listed in the Declaration prevail over the laws adopted by

\footnotetext{
${ }^{1}$ Dissenting Opinion of the Justice of the Constitutional Court Ineta Ziemele in the Case Nr. 2014-08-03, para 5. http://www.satv.tiesa.gov.lv/wp-content/uploads/2016/02/201408-03_Atseviskas_domas.pdf. Viewed 5.11.2015.
} 
the Parliament in the hierarchy of legal norms. ${ }^{2}$ Back in 1997, Levits E. wrote: "Meeting the provisions of articles 69 and 70 of the Association Agreement between Latvia and the European Union as of 12 June 1995, Latvia should not only agree on the texts of its regulatory acts with the texts of the European Union's legal norms, but also adopt the theory of Western law, namely, the legal thinking, because only then the legislation, coordinated at the level of wording, will be practically enforced in Latvia in the same way as in the European Union. Common understanding of the rights within the traditions of the European legal culture, forms a baseline for due functioning of the European Union".

The former Chairman of the Constitutional Court Aivars Endziņš presented another point of view in 2004: "On the one hand, we can agree to a certain extent with the general opinion that in case of a conflict, the European Union's law takes precedence over the national laws, and the priority of applying the legal acts of the European Union is absolute. At the same time, it should be borne in mind that the national constitutional norms are not unified. Every Constitution contains the provisions that establish the constitutional foundations of the state. Usually, a much more complicated procedure is used to amend the rules, where some of them cannot be altered. These rules do not have and can not have inferior legal effect than the EU documents". ${ }^{4}$

And further, replying to the author's questions posed on 25.11.2015, Professor Aivars Endziņš adds: "The situation when ECHR finds violation of the Convention in legal consideration by the courts of Latvia is not uncommon. However, the limitation of rights guaranteed by the Constitution is not possible in principle, since the provisions of the Convention and the Charter of Fundamental Rights of the European Union suppose a wider spectrum of basic rights and freedoms than the Constitution of the Republic of Latvia.",5

The opinion of Vice-President of the Constitutional Court of the Republic of Latvia Uldis Ķinis is important as well: "The international rules are

${ }^{2}$ Levits Egils."Human Rights Norms and their Legal Rank in the Latvian Legal System”. Human Rights Quarterly No. 6.

${ }^{3}$ Levits E. Latvijas un Eiropas Savienības tiesību sistēmu tuvināšana un tiesiskas valsts principu īstenošana // Latvija un Eiropas Savienība, 1997, nr.6, 30.-45. lpp.

${ }^{4}$ Endziņš Aivars. The position of Constitutional Courts following integration into the European Union. Bled, Slovenia, 30 September - 2 October 2004. http://www.usrs.si/media/zbornik.pdf. Viewed 5.11.2015.

${ }^{5}$ Endziņš Aivars, the replay from 25.11.2015 to the questions asked by the author in an interview. 
not more priority-oriented than the norms of the Constitution...Limitation of rights guaranteed by the Constitution is not possible in principle, since the provisions of the Convention and the Charter of Fundamental Rights of the European Union suppose a wider spectrum of basic rights and freedoms than the Constitution of the Republic of Latvia."

On 10 December, 2015, ECHR judge Mits Martins gave the reply to the author: "From a perspective of the ECHR, its obligations cannot be set aside by referring to domestic law, including the Constitution (Vienna Convention on the Law of Treaties). ${ }^{7}$ At the same time in an interview Mits Martins replied that: "... you can use my book "European Convention on Human Rights in Latvia: Impact on Legal Doctrine and Application of Legal Norms", ${ }^{8}$ where Mits Martins pointed out that "in the light of the statement of non-superiority of international treaties to the Constitution, indicated that in case of a clear conflict between the Constitution and international treaties the Constitution would prevail."

The author refers to the opinion of a former judge of the Constitutional Court of the Republic of Latvia, Juris Jelāgins. "Only the international rules that have the same legal effect as the provisions of the Constitution have higher priority than the norms of the Constitution of the Republic of Latvia. If a contradiction between some ratified norm of the Convention and the norms of the Constitution is detected, this collision may be eliminated either by changing the relevant article of the Constitution of the Republic of Latvia or by denunciation of the Convention's norm." 9

The priorities and values of the sovereign state are emphasized by the former president of the Constitutional Court Gunārs Kūtris: "If viewed from the position of «pure» theory of the rules of law hierarchy, the international norms need to be recognized as having a higher priority. At the same time, the issue is complicated by the norms of the European Union that are traditionally referred to as supranational, rather than international. Still I believe that the

\footnotetext{
${ }^{6}$ Kinis Uldis, the replay from 25.11 .2015 to the questions asked by the author in an interview.

${ }^{7}$ Mits Martins, the replay from 15.12.2015 to the questions asked by the author in an interview.

${ }^{8}$ Mits, Martins. European Convention on Human Rights in Latvia: Impact on Legal Doctrine and Application of Legal Norms. Media Tryck, Lund, 2010, 296. ISBN 9789984-49-011-3.

${ }^{9}$ Jelāgins Juris, the replay from 9.2 .2016 to the questions asked by the author in an interview.
} 
Constitution is above all, that is, it is more prioritized. The right to participate in international organizations and take on the obligation arising from the international obligations follows from the rules of the Constitution of a sovereign state. So, the Constitution allows for action in accordance with the international norms on the territory of the state. It would be absurd if an international norm (possibly, improperly formulated and adopted by majority of votes) would challenge or threaten the values fixed in the Constitution of a sovereign state." 10

The author supports the view of the Chairman of the Constitutional Court of the Republic of Armenia G. Harutyunyan: "The foremost task of the constitutional control globally is to ensure supremacy of the Constitution. Today, in 110 countries of the world, it is enforced according to the European model - through special bodies of judicial constitutional control, and in 48 countries - according to the American model. However, the variations within the European model are so diverse that it is difficult to consider them on the same plane." 11

The same view is shared by former Chairman of the Supreme Court of the Republic of Finland, ECHR Judge Pauliine Koskelo (from $1^{\text {st }}$ January, 2016, who held a position at the Supreme Court from 2000 and as a President of the Supreme Court from 2006). In Finland, the supremacy of the Constitution is enshrined by article 106. In accordance with the constitutional norms, the Constitution defends the fundamental human rights and freedoms and promotes effectuation of justice in the society. ${ }^{12}$ If the application of an Act would be in an evident conflict with the Constitution, the court of law shall give supremacy to the provision in the Constitution.

These principles are reflected in the judgements of the Constitutional Courts of European states. The Constitutional Courts of the Federal Republic of Germany, Austria and Italy, as well as the Supreme Court of the United Kingdom of Great Britain and Northern Ireland, recognized the priority of the Constitution. Similar decisions to reject the legal position of the European Court because of its contradiction to the principles of the national Constitution were taken by the Constitutional Courts of France and Switzerland.

\footnotetext{
${ }^{10}$ Kūtris Gunārs, the replay from 15.12 .2015 to the questions asked by the author in an interview.

11 Арутюнян Г. Особенности конституционных судов в условиях общественной трансформации. “Конституционное правосудие” Москва. 2011. № 1. С. 41-48.

${ }^{12}$ Koskelo Pauliine, the replay from 10.1.2016 to the questions asked by the author in an interview.
} 
As an example, the author refers to a similar practice of defending the fundamental national rights by the Federal Constitutional Court of the Federal Republic of Germany, which relies on the legal position, regarding the "restricted judicial validity of ECHR's rulings". The Federal Constitutional Court of Germany formulated the principle of the priority of the national constitution to the judgements of the European Court: The text of the EHRC and the practice of ECHR serve as means of interpretation on the level of constitutional law to determine the contents and scope of fundamental rights and the principle of the law-governed state, as far as it does not lead to decrease or limitation of fundamental rights, included in the Basic Law. ${ }^{13}$

The Constitutional Court ruled, as early as in 2005, that international norms of human rights and the practice of applying them on the level of constitutional law serve as a means of interpretation for establishing the content and scope of fundamental rights and the principles of a judicial state, insofar this does not lead to decreasing or restricting the human rights that are included in the Satversme. ${ }^{14}$

The research and analysis of legal practice make it possible to conclude that enforcement of laws at the state level is a prerogative falling under the competence of every sovereign state on the basis of the Constitution.

\section{Brief summary of Chapter 1}

After accession to the European Convention, significant changes were made in the national legislation of the member countries of the Convention; in particular, in 1998 the Constitution of the Republic of Latvia was supplemented by section 8 on the fundamental human rights, and in 2000 an opinion was expressed by the Constitutional Court that, in interpreting the regulations included in section 8 of Constitution of the Republic of Latvia, their opposition to the core values of democracy as contained in section 1 of the Constitution is impermissible.

The Constitution of the Republic of Finland of 1919 was complemented in 1999 with amendments on the supremacy of the Constitution. The Supreme

\footnotetext{
${ }^{13}$ German Federal Constitutional Court October 142004 . Judgment in the case 2BVR $1481 / 04$.

http://www.bundesverfassungsgericht.de/SharedDocs/Entscheidungen/EN/2004/10/rs20 041014_2bvr148104en.html. Viewed 5.11.2015.

${ }^{14}$ Judgment of 13 May 2005 by the Constitutional Court in Case Nr. 2004-18-0106, para 5 of the Findings. http://www.satv.tiesa.gov.lv/en/cases/. Viewed 16.11.2015.
} 
Court and the Supreme Administrative Court of the Republic of Finland accept the interpretation of the Convention by the European Court as compulsory and are guided by it, when justifying their judgement - if it is not contrary to the Constitution as a statutory act of supreme legal force.

Also ECHR, particularly within the period 1979-2010, repeatedly recommended that the national authorities, in particular courts, gave priority to the interpretation and enforcement of internal legislation and to judgements based on issues of constitutionality.

A different approach could result in diminution of the role of the Constitution as an act of supreme legal force valid on the territory of the country, and therefore - in undermining the foundations of the constitutional order and state sovereignty.

Emphasizing the role of the international law and in particular the European Convention, as expressed in the judgements of European Court of Human Rights, the author considers the protection of basic human rights and freedoms to be a paramount factor, as well as compliance with the requirements of fair judicial trial in accordance with the provisions of the Constitution, unless this results in mitigation or limitation of the fundamental rights provided by the Constitution.

The answer to the question explored in the research is confirmed as well by the response received from the former judges of ECHR and the constitutional law experts of the Republic of Latvia and the Republic of Finland, as well as by the conclusions based on judgements of the Constitutional Courts of the European countries, of the Supreme Court of the Republic of Latvia and the Supreme Court of the Republic of Finland. 


\section{THE RIGHT TO A FAIR TRIAL BY AN INDEPENDENT AND IMPARTIAL TRIBUNAL ESTABLISHED BY LAW}

Article 6 of the Convention is the most common norm in the practice of considering cases by ECHR; it guarantees the right to fair trial. ECHR adheres to the view that the right to fair trial is respected if a person in question is entitled to receive a consistent court judgement on its rights and responsibilities and may be convinced that this resolution would not be cancelled after a certain period of time.

The right to fair trial is also provided by enforcement of articles 5, 7 and 13 of the Convention. The European Court and the Commission confirm the conclusion that Article 13 is in the subordinate position relative to Article 6. For instance, clause 1 of article 6 strengthens and develops a number of guarantees provided by Article 13. First, the right to effective national remedies is applicable not only in case of alleged violation of one of the rights and liberties guaranteed in the Convention, but also in the event of breach of any "civil right" within the meaning of clause 1 of Article 6 .

Second, clause 1 of Article 6 guarantees the right of accessing court, while the term "remedies involving participation of national authorities" is so broad that it pertains to the procedures other than judicial. ${ }^{15}$

Third, while it is commonly accepted that national courts may not directly apply the provision of Article 13, such "application" is permissible within the framework of Article 6, which empowers one to use such a reference in national courts of the countries where the Convention is deemed to be a part of the internal law of the state.

ECHR repeated in the case of Lavents v. Latvia that national courts deal with the domestic law, including the rules applying to establishment and procedures for the courts, in the first place, while the supervisory role of the European Court manifests itself only in cases of apparent non-compliance with the relevant laws. In this case, the Court reminded that, in accordance with clause 1 of article 6 , the court must always be set up on the basis of law. This expression reflects the principle of supremacy of law inherent in the entire system of the Convention and its Protocols.

\footnotetext{
${ }^{15}$ Case of Golder v. the United Kingdom. No 4451/70. 21 February 1975. http://hudoc.echr.coe.int/eng\#\{ "fulltext":["Golder\%20v.\%20the\%20United\%20Kingdo m"],"documentcollectionid2":["GRANDCHAMBER","CHAMBER"],"itemid":["00157496"]\} Viewed 5.12.2015.
} 
Article 6 should be interpreted in view of the present-day conditions, with regard for the governing economic and social conditions, within the framework of the so-called concept "The Convention as a living organism" as defined in a ruling in the case of Marckx v. Belgium: However, the Court recalls that this Convention must be interpreted in the light of present-day conditions. In the instant case, the Court cannot but be struck by the fact that the domestic law of the great majority of the member States of the Council of Europe has evolved and is continuing to evolve, in company with the relevant international instruments, towards full juridical recognition of the maxim "mater semper certa est". 16

The author states that the violation of article 6 of the Convention is the most common recognized breach on the part of Finland. In total, ECHR found 98 cases of infringement of article 6 of the Convention in the period 19952015. Latvia violated the norms of article 6 of the Convention 27 times within the period 1997-2015.

At the same time, the Constitutional Court of the Republic of Latvia pointed out on 9 January 2014, case 2013-08-01, that ECHR had repeatedly recognized the fact of infringement of the right to fair judicial trial in cases where the court judgement that entered into force was revoked and revised on the basis of a note (protest) of Attorney General, and emphasized that in such cases the right to fair trial was illusory. There is a statement in the same case, in Clause 7 of Conclusion to the Constitutional Court judgement: The international standards in the sphere of human rights and the practice of their enforcement at the level of constitutional rights serve as a means of interpretation in assessing the content and scope of the fundamental rights and principles of the law-governed state to the extent this does not lead to mitigation or limitation of the fundamental rights provided by the Constitution. ${ }^{17}$

The author refers to the explored material of all cases filed in 2015. The court dismissed 1150 claims requesting review of cases by the Supreme Court,

\footnotetext{
${ }^{16}$ Case of Marckx v. Belgium, No 6833/74. 13 June 1979, para 41. http://hudoc.echr.coe.int/eng\#\{"fulltext":["Marckx"],"documentcollectionid2":["JUDG MENTS","DECISIONS","COMMUNICATEDCASES","CLIN","REPORTS","RESOL UTIONS"],"itemid":["001-57534"]\}. Viewed 4.1.2016.

17 Judgment of 13 May 2005 by the Constitutional Court in the case Nr. 2004-18-0106, para 5 and Judgment of 18 October 2007 in the case Nr. 2007-03-01, para 11. http://www.satv.tiesa.gov.lv/en/cases/. Viewed 4.1.2016.
} 
including a prosecutors' suit with regard to Auer case claiming revision of cancellation of life imprisonment. ${ }^{18}$

According to the author, the case KКО:2015:14 is most exemplary; it was referred to by Pauliine Koskelo, among the others, - the former President of the Supreme Court of Finland and ECHR judge from 1.1.2016, when she responded to the questions posed by the author in the questionnaire. ${ }^{19}$

The Judicial panel of the Supreme Court composed of 18 judges overturned the verdict of the Court of Appeal as of 6.9.2012 regarding two serious tax crimes, grave offense in the sphere of accounting, felony crime of tax debtor and registration offence by Jan Atso Tervonen and returned the case for investigation by the district court in fullest detail.

The Supreme Court found a violation of articles 21 and 106 of the Constitution and Article 1 of Article 63 ) to the Convention on the right to defend himself in person or through legal assistance of his own choosing in the proceedings. $\S 106$ of the Constitution is applied in cases where the proceedings by the court and the application of the law would be in clear contradiction with the Constitution, in which the court is required to give preference to the Constitution.

In 2015 the author has studied 54 cases of the Department of Criminal Cases of the Supreme Court of the Republic of Latvia, 26 cases of the Department of Civil Cases as well as 51 cases of the Department of Administrative Cases. Also, 14 Reports by the Committee of Ministers of the Council of Europe on the reports of the Government of the Republic of Latvia for the implementation of ECHR decisions for the period from 20 June 2013 5 October 2015 we thoroughly investigated.

The author has studied and bases his research with references to legal precedents of handed down decisions and reviews of 172 cases by the Supreme Court of the Republic of Finland for the period 2010-2015, 87 decisions of 2015 and 167 decisions of the Supreme Administrative Court of Finland from 2015.

Case-law of the Republic of Latvia Supreme Court shows that the European Convention refers to important legal instruments, which must be taken into account when deciding on the case. A good example is a report made

\footnotetext{
18 Judgment of Appeal Court of Vaasa. Judgment VaaHO:2015:2 on 19 February 2015. www.finlex.fi. Viewed 9.1.2016.

19 Judgment of Supreme Court of Finland. KKO:2015:14. 17.February 2015. www.finlex.fi. Viewed 9.1.2016.
} 
by the Government of the Republic of Latvia on the implementation of ECHR decisions in a case of Deniss Čalovskis from 2 October 2015 DH-DD (2015) $1016 .^{20}$

The Government acknowledged that the lack of knowledge of the Convention standards by national judges has led to the violation of Article 5, paragraph 1, of the Convention. The Latvian authorities have worked hard to improve the knowledge and practice of the courts and on the $1^{\text {st }}$ October 2015 Parliament adopted amendments to the relevant parts of the Criminal Procedure Act, including section dealing with the extradition of persons, and in particular the amendments to provide additional oversight mechanisms and the right to provide prosecutors the power to immediately release individuals from detention in the case of rejection of extradition.

According to the report of the Committee of Ministers of the Council of Europe DH-DD (2015) 1005 on the case A.K. v. Latvia, ${ }^{21}$ noted that the Convention has a direct effect on the legal system of Latvia. In order to improve the understanding of the Courts' findings and standards, analysis of this decision was included in the Latvian judicial program (Latvian Judicial Training Centres' programme) for judges of district courts and the Supreme Court. For example, judicial practice, found that the shortcomings identified by the court, in this case have individual character, and that in general the national courts apply the standards of the Convention on Human Rights, established by the case law of the ECHR.

In comparison with the consideration of such cases in Latvia, the Supreme Court of the Republic of Finland is much more likely to apply numerous references to judicial precedent ECHR and legal positions, developed by the European Court of Justice to clarify or application of the rules of the Convention in matters relating to the provision of the right to a fair trial and to judicial Supreme Court precedent.

The most meaningful reference to international agreements, directives and decisions of the ECHR and the Court of Justice of the European Union are

\footnotetext{
${ }^{20}$ Case of Čalovskis v.Latvia. Application No 22205/13. 24 July 2014. http://hudoc.echr.coe.int/eng\#\{"fulltext":["\%0Calovskis\%20v.Latvia"],"documentcollect ionid2":["GRANDCHAMBER","CHAMBER"],"itemid":["001-145791"] _ Viewed 20.1.2016.

${ }^{21}$ Case of A.K.v.Latvia, No 33011/08, 24 June 2014. http://hudoc.echr.coe.int/eng\#\{"fulltext":["33011/08,\%2024\%20June\%202014"],"docu mentcollectionid2":["GRANDCHAMBER","CHAMBER"],"itemid":["001-145005"]\} Viewed 20.1.2016.
} 
the decisions of the Supreme Administrative Court of the Republic of Finland to review the decisions of the Immigration Office. As an example, one of the last decisions of 2015 KHO:2015:113 on 28 pages, references to the Dublin agreement, the Association Agreement between the Republic of Turkey and the European Economic Community in 1963, 18 references to the decisions of the European Union Court of Justice and to the previously made by two decisions of the Supreme Administrative Court. In order to avoid wrong interpretation of the Court refers to the translation triple translating the terms of Article 14 of the Agreement on German, French and English with the reference to the decision of the European Union Court of Justice. ${ }^{22}$

As noted in Thesis Chapter 3.4, when considering claims for cancellation of in force decisions on the basis of the ECHR Resolution on the recognition of a violation by Finland of articles of the Convention, the Court refers to numerous decisions of the European Court of affecting the interests of Finland and the other member countries of the Convention, details examining and comparing the circumstances of each case. At the same time the final basis for a decision is based on the national Constitution.

As the most detailed examination of the case, by the Supreme Court of the Republic of Latvia, the author refers to a decision from August 82015 SKK-303/2015 which contains references to the legal position of the European Court of Justice with reference to the 7 ECHR decisions which are not related to the interests of Latvia, but without reference to a specific article of the Convention. $^{23}$

In the case of SKK $-549 / 2015^{24}$ from 28.12.2015 referred to 6 ECHR judgments by the Constitutional Court and 4 decisions of the Department of Criminal Cases and concluded that the Latgale Regional Court did not take

${ }^{22}$ C-37/98, Savas, ECLI:EU:C:2000:224. http://curia.europa.eu/juris/showPdf.jsf?text $=\&$ docid $=45263 \&$ pageIndex $=0 \&$ doclang $=\mathrm{E}$ $\mathrm{N} \&$ mode $=1$ st\&dir $=\&$ occ $=$ first $\&$ part $=1 \& \operatorname{cid}=136395$ Viewed 22.1.2016.

${ }^{23}$ Case of Malininas v. Lithuania, case of Edwards and Lewis v. the United Kingdom, case of Sequeira v. Portugal, case of Pyrgiotakis v. Grece, case of Teixeira de Castro v. Portugal, case of Vanyan v. Russia, case of Ramanauskas v. Lithuania. http://hudoc.echr.coe.int/eng\#\{"documentcollectionid2":["GRANDCHAMBER","CHA MBER"]\}.Viewed 23.1.2016.

${ }^{24}$ Judgment of 25 Decembre 2015 by the Department of Criminal Cases of the Supreme Court in the case Nr. SKK -549/2015. http://at.gov.lv/en/court-proceedings-in-thesupreme-court/archive-of-case-law-decisions/department-of-criminalcases/chronological-order/. Viewed 23.1.2016. 
adequate measures to study of the evidence in accordance with the provisions of Resolution by European Court of Justice and the Supreme Court.

The basic principles of criminal law, including human rights guarantees and the right to a fair trial are considered in the decision of the Supreme Court SKK-21/2014 from February 12, 2014 and March 272014 in the case SKK39/2014. European Court of Human Rights made the conclusions that can be attributed to a specific criminal case.

Department of Civil Cases of the Republic of Latvia Supreme Court considered 16 decisions in 2015, of which we can state the following:

As the most complete combination of compliance of the Constitution, the judicial precedents of the ECHR and the European Court of Justice the author cites a decision of the Supreme Court SKC-1427/2015 ${ }^{25}$. In this case, the Court used many references to the Constitution, decisions of the ECHR, the European Court of Justice and the European Parliament and the European Council. In particular, the Supreme Court referred to article 105 of the Constitution, the 3 decisions of the $\mathrm{ECHR}^{26}$ and 6 judicial precidents of the European Court of Justice. $^{27}$

In 2015 the Department of Administrative Cases of the Supreme Court in the case of SKA-864-15 alone has referred to three citations of the articles of the Constitution and two decisions of the ECHR: case of KU v. Finland and case of Hannover v. Germany.

In the decision SKA-237-15 Court has referred to Article 8 of Convention and to case of Marper v. United Kingdom. In the case of SKA-241-15 the Court referred on 8 Article of Convention as well.

The author notes that shining examples of reaction to ECHR decisions are cases "V.S. v Latvia" and "Slivenko v. Latvia". The Supreme Court overturned the previous court decisions and ruled on the resumption of the trial

\footnotetext{
25 Judgment of 13 May 2015 by the Department of Civil Cases of the Supreme Court in the case Nr.SKC-1427/2015. http://at.gov.lv/en/court-proceedings-in-the-supremecourt/archive-of-case-law-decisions/senate/chronological-order/.Viewed 23.1.2016.

${ }^{26}$ Wiggins v. United Kingdom, 1978, case of Mellacher and Others v. Austria. 1989, case of Tre Traktorer AB v. Sweden.

http://hudoc.echr.coe.int/eng\#\{"documentcollectionid2":["GRANDCHAMBER","CHA MBER"]\}.Viewed 23.1.2016.

27 Case-law of the Court of Justice. C-619/10 Trade Agency Ltd v. Seramico Investments Ltd, C-7/98 Krombach, C-420/07 , Apostolides, C-38/98 Renault, C391/95 Van Uden, C-104/03 Ste Paul Dairy Industries. http://fra.europa.eu/en/caselawreference/cjeu-c-61910-judgment.Viewed 23.1.2016.
} 
and sent the case to the Riga Regional Court as the appellate court. These decisions cannot be appealed.

According to the author, the best example of cases and respect for the right to a fair trial are the decisions of the Constitutional Court of the Republic of Latvia. For example, a decision on the case Nr. 2014-09-01 from November 28, 2014 contains a 53 page decision, references to Articles 1 and 92 of the Constitution, 46 decisions of the Constitutional Court or the case materials, 5 ECHR judgments, Article 6 of the Convention, one decision of the European Commission, the two decisions of the Department of Civil Cases of the Supreme Court No SKC-20/2013, SKC-1627/2014, the UNCITRAL 2012.

This decision, as well as many others, which were previously shown in this study indicate a clear position of the Constitutional Court of the Republic of Latvia, the fundamental value of the European system of protection of the rights and freedoms of man and citizen in the legal system and to identify shortcomings of the national legal regulation and the proposal on ways to address them.

\section{Brief summary of Chapter 2}

In the period from 1959 to 2015 the Court of Strasbourg issued 15, 570 Regulations, which established at least one violation of the Convention. The violations of Article 6 of the Convention were identified 10,145 times, of which 4,329 are set for violation of the right to a fair trial.

The analysis of judgements of the Latvian Constitutional Court demonstrates its definite position regarding the fundamental value of the European system of protection of the rights and freedoms, expressed in consistent implementation of the Convention provisions and ECHR resolutions by the Court in the legal system, and in respect of identifying weak points of the national legal regulation and proposing the ways to eliminate them.

The same conclusion follows the reports of the Cabinet of Ministers of the Republic of Latvia, which notes that the Convention has a direct impact on the legal system of Latvia. It was established, through examples of the judicial practice, that the shortcomings identified by the court, were of individual character in this case and that in general the national courts do apply the standards of the Convention on Human Rights established by the decisional law of ECHR. 
The position of the author coincides with the answers posed within the framework of the research to the former judges of the European Court, former Chairmen and judges of the Constitutional Court of the Republic of Latvia and the President of the Supreme Court of the Republic of Finland; it is also confirmed by the judgements of the Constitutional Court of the Republic of Latvia and the Supreme Court of the Republic of Finland. 


\section{REVIEW OF LAWSUITS IN THE SUPREME COURT OF THE REPUBLIC OF LATVIA AND THE REPUBLIC OF FINLAND}

It is important to note that as to the argument based on the backlog of cases in the appellate court, it must not be forgotten that Article 6 para. 1 (art. 6-1) imposes on the Contracting States the duty to organise their judicial systems in such a way that their courts can meet each of its requirements. ${ }^{28}$ Undoubtedly, the demand for fair judicial trial is one of the most important rights guaranteed by the European Convention on Human Rights and Fundamental Freedoms. However, the issue of realization of this right is controversial among the legal scholars and law enforcers, which problem is only aggravated by the rulings of ECHR.

For instance, back in 1975 in the case of Golder v. the United Kingdom the Court held that the procedural guarantees laid down in Article 6 concerning fairness, publicity and promptness would be meaningless in the absence of any protection for the pre-condition for the enjoyment of those guarantees, namely, access to court. It established this as an inherent aspect of the safeguards enshrined in Article 6, referring to the principles of the rule of law and the avoidance of arbitrary power which underlie much of the Convention. ${ }^{29}$

As an example, in Fogarty v. the United Kingdom the Court recalls that the Convention has to be interpreted in the light of the rules set out in the Vienna Convention of 23 May 1969 on the Law of Treaties. ${ }^{30}$

Also in the case of Bosphorus Hava Yolları Turizm v Ticaret Anonim Şirketi v. Ireland, the Convention must be interpreted in such a manner as to allow States Parties to comply with international obligations so as not to thwart

${ }^{28}$ Case of Salesi v. Italy. No 13023/87, 26 February 1993, para 24.

http://hudoc.echr.coe.int/eng\#\{ "fulltext":["Salesi\%20v.\%20Italy"],"documentcollectioni d2":["GRANDCHAMBER","CHAMBER"],"itemid":["001-57814"]\}.Viewed 2.2.2016.

${ }^{29}$ Case of Golder v. the United Kingdom. 21 February 1975, para 28-36.

http://hudoc.echr.coe.int/eng\#\{ "fulltext":["golder"],"documentcollectionid2":["GRAND CHAMBER","CHAMBER"],"itemid":["001-57496"]\}.Viewed 2.2.2016.

${ }^{30}$ Case of Fogarty v. the United Kingdom. No 37112/97. 21 November 2001, para.35. http://hudoc.echr.coe.int/eng\#\{ "fulltext":["Case\%20of\%20Fogarty\%20v.\%20the\%20Un ited\%20Kingdom"],"documentcollectionid2":["GRANDCHAMBER","CHAMBER"],"it emid":["001-59886"]\}"]\}.Viewed 2. 2.2016. 
the current trend towards extending and strengthening international cooperation. ${ }^{31}$

In these cases, varying provisions of the legislation of the European Union countries are challenged from ECHR's point of view.

The author accentuates the position of ECHR: Court notes that in constitutional complaint proceedings the Constitutional Court has no jurisdiction to review the compatibility of legislation with international agreements, including the Convention. ${ }^{32}$

This position totally contradicts the Constitution of the Republic of Latvia and the earlier enactments of the Constitutional Court.

The ECHR has repeatedly pointed out in the decisions that the right to a fair hearing before a tribunal as guaranteed by Article $6 \S 1$ of the Convention must be interpreted in the light of the Preamble to the Convention, which declares, among other things, the rule of law to be part of the common heritage of the Contracting States. One of the fundamental aspects of the rule of law is the principle of legal certainty, which requires, inter alia, that where the courts have finally determined an issue, their ruling should not be called into question. ${ }^{33}$ The Court reiterates that Article $6 \S 1$ secures to everyone the right to have any claim relating to his civil rights and obligations brought before a court or tribunal. In this way it embodies the "right to a court", of which the right of access, that is the right to institute proceedings before courts in civil matters, constitutes one aspect. However, that right would be illusory if a Contracting State's domestic legal system allowed a final, binding judicial decision to remain inoperative to the detriment of one party. It would be inconceivable that Article $6 \S 1$ should describe in detail procedural guarantees afforded to litigants - proceedings that are fair, public and expeditious without protecting the implementation of judicial decisions; to construe Article

\footnotetext{
${ }^{31}$ Case of Bosphorus Hava Yolları Turizm ve Ticaret Anonim Şirketi v. Ireland, No 45036/98, 30 June 2005, para 108. http://hudoc.echr.coe.int/eng\#\{"fulltext":["45036/98"],"documentcollectionid2":["GRA NDCHAMBER","CHAMBER"],"itemid":["001-69564"]\}.Viewed 26.2.2016.

${ }^{32}$ Case of Henryk Urban and Ryszard Urban v. Poland. No 23614/08. 30 November 2010, final 28 February 2011, para 51.

http://hudoc.echr.coe.int/eng\#\{"fulltext":["Urban\%20and\%20Ryszard\%20Urban"],"item id":["001-101962"]\}.Viewed 26.2.2016.

${ }^{33}$ Case of Brumărescu v. Romania, No 28342/95, 28 October 1999, para 61. http://hudoc.echr.coe.int/eng\#\{ "fulltext":["Case\%20of\%20Brum\%03rescu\%20v.\%20Ro mania,"],"documentcollectionid2":["GRANDCHAMBER","CHAMBER"],"itemid":["00 $1-58337 "]\}$.Viewed 26.2.2016.
} 
6 as being concerned exclusively with access to a court and the conduct of proceedings would likely lead to situations incompatible with the principle of the rule of law which the Contracting States undertook to respect when they ratified the Convention. ${ }^{34}$

The Constitutional Court of the Republic of Latvia expresses the opinion, that the Saeima recognises that in accordance with the principle of legal security, res judicata principle also falls within the scope of the right to a fair trial. Allegedly, it provides that a binding court ruling that has entered into force is final, i.e., the re-examination of such rulings with the purpose of achieving that the case is examined de novo should be inadmissible. However, it is said that the right to a fair trial is not absolute and restriction of this right is admissible. ECHR has also found that in some cases departures from res judicata principle were admissible. ${ }^{35}$

The author notes that in recent years the Supreme Court of the Republic of Latvia has had this practice of responding to ECHR judgements. A demonstrative example of this is the cases V.S. v. Latvia and Slivenko v. Latvia. The Supreme Court overturned the previous judgements and ruled to resume the trial; it sent the case to Riga Regional Court being a court of appellate jurisdiction. These judgements cannot be appealed against.

According to the Recommendation R (2000) 2 in exceptional cases, the most effective way to a new investigation of the case is for the applicant to return to an earlier stage. As an example, in particular, where the applicant after the decision by Court of Human Rights is still suffering post sentence of a national court as a consequence of serious adverse effects that cannot be fixed without a new investigation at the national level. An example of the consequences specified in the recommendation of a long prison sentence, which the convicted person is still serving. ${ }^{36}$

Recommendation encouraged all Contracting Parties to ensure that their national legal systems have the necessary abilities to achieve, as far as possible,

\footnotetext{
${ }^{34}$ Case of Ryabykh v.Russia. No 52854/99. 24 July 2003, para. http://hudoc.echr.coe.int/eng\#\{"fulltext":["Ryabykh"],"documentcollectionid2":["GRAN DCHAMBER","CHAMBER"],"itemid":["001-61261"]\}. Viewed 6.4.2016.

35 Judgment of 9 January 2014 by the Constitutional Court in case Nr. 2013-08-01. http://www.satv.tiesa.gov.lv/en/cases/. Viewed 2.4.2016.

${ }^{36}$ Recommendation No. R (2000) 2 of the Committee of Ministers to member states. https://www.coe.int/t/dghl/monitoring/greco/documents/Rec(2000)10_EN.pdf. Viewed 2.4.2016.
} 
restitutio in integrum, and in particular to provide appropriate opportunities for case review, including the reopening of the case.

The author emphasizes that currently, the national law of many European countries provides for the review of judicial decisions, which have entered into force, in order to remedy the consequences of the violations found by the European Court.

In practice, the Supreme Court of the Republic of Finland, for example, in the decision (KKO:2009:84) ${ }^{37}$ found that the European Convention on Human Rights as such does not oblige participating States to engage in the cancellation or annulment of the sentences of national courts in the statement of the European Court of violations of Article 6 of the Convention for fair trial. It is important to note, in particular, the Supreme Court often refers to the earlier decision KKO:2008:24 ${ }^{38}$, which established that a conviction does not mean that the earlier made decision of the national court should be lifted.

The author has studied and bases his research with references to legal precedents of handed down decisions and reviews of 172 cases the Supreme Court of the Republic of Finland for the period 2010-2015. As such an example, the author cites the demonstrative decision made by the Supreme Court of Republic Finland in KKO:2011:109, the Supreme Court twice in 2011 returned the criminal case of Jippii Group Oyj for the review by the Court of Appeal of Helsinki. The Supreme Court referred to $21 \S$ of the Finnish Constitution and article 6 of the European Convention, found 14 accused to be not guilty, abolished all 26 counts in the indictment and ordered the state to pay the defendants approximately 4 million euros legal costs.

During the study, 151 ECHR judgments against Finland in the period 1995-2015 year were analysed, which found violations of articles of the Convention. From this analysis, consideration of the grounds for rejection of claims absolving prior rulings by the national courts the author makes the following conclusions.

1. In accordance with the provisions of Article 46 of the Convention, interpreted by taking into account the recommendations of the Committee of Ministers of the Council of Europe NR (2000) 2 on January 19, 2000 "to review the cases and resumption of proceedings at domestic level following

\footnotetext{
${ }^{37}$ Judgment of Supreme Court of Finland , case of Eino Laaksonen on 27.10.2009. www.finlex.fi. Viewed 1.3.2016.

${ }^{38}$ Judgment of Supreme Court of Finland, case of Selistö on 14.03.2008. www.finlex.fi. Viewed 4.3.2016.
} 
judgments of the European Court of Human Rights", the basis for judicial review of the act due to new circumstances is not only based of violation by Finland established in the European Court but also the Convention or the Protocols. In this regard, it should be appreciated that a judicial act is subject to review in the event that the applicant continues to suffer the adverse effects of such an act and paid compensation to the applicant awarded by the Court pursuant to Article 41 of the Convention does not provide a remedy and freedoms.

2. When a court considers whether to revise the judicial act a causal link between the breach of the ECHR Convention and the adverse consequences that the applicant continues to suffer should be considered.

3. The principle of the presumption of innocence, provisions of paragraph 2 of Article 6 of the Convention, is one of the main aspects of a fair trial in the criminal case law.

4. On the basis of Article 46 of the Convention, taking into account recommendations for revision in case of violation of the procedural rights of individuals found by the European Court, the Supreme Court in the revision of the judicial act must eliminate the violation of the Convention or the Protocols thereto. The Supreme Court must take the same stance as a court in Strasbourg and adopt a final judicial act, instead of taking the decision to return the case to the appellate court.

The European Court of Human Rights has repeatedly pointed out that the execution of the decision rendered by any court must be regarded as an integral part of a fair justice - otherwise, if the national legal system permits that a final, binding judicial decision may remain unfulfilled, " right to a court "becomes illusory (Case of Hornsby v. Greece). Execution of a judgment given by any court must therefore be regarded as an integral part of the " trial " for the purposes of Article 6 (art. 6).

In 2009 the ECHR has made a number of important legal positions: it should be pointed out that one of the most significant features of the Convention system is that it includes a mechanism for reviewing compliance with the provisions of the Convention. Thus, the Convention does not only require the States Parties to observe the rights and obligations deriving from it, but also establishes a judicial body, the Court, which is empowered to find 
violations of the Convention in final judgments by which the States Parties have undertaken to abide (Article 19, in conjunction with Article $46 \S 1$ ). ${ }^{39}$

\section{Brief summary of Chapter 3}

Relations between international law and national law of the Member States of the European Convention is characterised by the fact that they complement and enrich each other.

According to Article 1 of the Convention, each Contracting Party shall ensure that everyone within its jurisdiction has the rights and freedoms defined by the Convention. European Court has repeatedly stated that one of the fundamental aspects of the rule of law is the principle of legal certainty, which requires inter alia, so that the final judgements by the courts do not cast even a shadow of doubt.

The Constitutional Court of the Republic of Latvia has repeatedly stated that the Saeima recognises the right to a fair trial not to be absolute and that certain limitations are permissible. The ECHR came to a similar conclusion that in certain cases derogation from the principle of res judicata is acceptable.

The Constitutional Court of the Republic of Latvia has repeatedly defined that international norms of human rights and their implementation at the level of constitutional law serve as means of interpretation, allowing to establish the content and scope of fundamental rights and the rule of law, to the extent that this interpretation does not lead to a reduction or limitation of the fundamental rights outlined in the Constitution.

The Supreme Court of the Republic of Latvia has developed a stable judicature in relation to the interpretation and application of constitutional norms. However, in some cases, lower courts did not comply with mentioned case law of the Supreme Court and at their own discretion apply the provisions of the law.

The Republic of Finland has enshrined the supremacy of the Constitution and in case a decision or any other by-law is in conflict with the

\footnotetext{
${ }^{39}$ Case of Verein Gegen Tierfabriken Schweiz (VGT) v. Switzerland, No 32722/02.30 June 2009.

http://hudoc.echr.coe.int/eng\#\{ "fulltext":["Verein\%20Gegen\%20Tierfabriken\%20Schw eiz"],"documentcollectionid2":["GRANDCHAMBER","CHAMBER"],"itemid":["00193265"]\}.Viewed 6.4.2016.
} 
Constitution or any other law, its application by the court or other authority is not allowed.

According to the principles of the case law the statement "in accordance with the law" is required not only as a measures for the legal bases in the national law but also to provide a certain level of quality of that law, providing accessibility by a persons involved and its subsequent affect. However, the ECHR has repeatedly stressed that in most cases it is up to national authorities, notably the courts, to interpret and apply national law.

As shown in the undertaken research, the greatest number of violations by national courts involves the infringement of Article 6 of the Convention. Judicial errors in imposing sentences by national courts and the increasing number of cases considered by higher courts form the need to change the legislative procedure and make reforms in the judicial system.

After the comparative analysis of the European countries' Constitutions, the judgements of ECHR, the Constitutional Court of the Republic of Latvia and the Constitutional Courts of European countries, as well as the judgements of the Supreme Court of Latvia and of Finland, the author proposes amendments to the laws of the aforementioned countries in accordance with the Constitution and close consideration for the provisions of the European Convention. 


\section{EQUALITY OF PARTIES AND FAIR TRIAL GUARANTEES FROM THE POSITION OF EUROPEAN COURT OF HUMAN RIGTHS}

Presumption of innocence is one of the fundamental principles of criminal justice. The right to the presumption of innocence is defined in paragraph 2 of Article 14 of the International Covenant on Civil and Political Rights and paragraph 2 of Article 6 of the European Convention, which states the right of everyone "to be presumed innocent until his guilt is proven according to law". The presumption of innocence is guaranteed not only by those provisions of the ICCPR and the ECHR; It is also supported by two rights, which state that everyone has the right not to be compelled to testify against himself or to confess guilt.

Paragraph 8 of the Constitution of Finland under the heading " No one shall be found guilty of a criminal offence or be sentenced to a punishment on the basis of a deed, which has not been determined to be punishable by an Act at the time of its committal. The penalty imposed for an offence shall not be more severe than that provided by an Act at the time of commission of the offence". ${ }^{40}$

As "requirement of impartiality of the court is a reflection of this principle", the European Court considers the presumption of innocence to be an integral element for the right to a fair trial. The decision in the case Deweer v. Belgium" (Application No 6903/75. 27 February 1980), says: "The presumption of innocence embodied in paragraph 2 is in addition to other rights, are the constituent elements of the concept of a fair trial in criminal cases."

For the first time a suspect's right to legal counsel was implemented at a constitutional level in the 6th Amendment to the US Constitution of 1787. Main content of this right in most countries is reduced to the right to request the legal assistance during the court proceedings, especially criminal, as well as in the event of a threat of criminal prosecution. Furthermore, the constitutions and the law generally recognises the right of the underprivileged and financially vulnerable to receive legal assistance free of charge.

\footnotetext{
40 The Constitution of the Republic of Finland 11 June 1999 (731/1999, amendments up to 1112 / 2011 included) . http://www.finlex.fi/fi/laki/kaannokset/1999/en19990731.pdf. Viewed 2.5.2016.
} 
Paragraph 3c of Article 6 consists of four articulate components, namely: 1) the right to defend himself in person (Foucher v. France. 18/3/1997), 2), under certain circumstances, through legal assistance of his own choosing (Campbell and Fell v. the United Kingdom, 28/6/1884), 3) if he has not sufficient means to pay for legal assistance, to be given it free when the interests of justice so require; (Murray v. the United Kingdom) and finally, 4) the right to practical and full legal assistance (Bogumil v. Portugal, 7/10/2008).

For the first time the value of a lawyer in the court hearing was assessed by European Court of Human Rights during the case review of Golder v. the United Kingdom $^{41}$, Airey v. Ireland ${ }^{42}$ and Artico v. Italy. ${ }^{43}$

The right to professional, qualified legal assistance of a lawyer is an integral part of the rule of law, which is enshrined in the constitutions of many countries. Results of the study enabled the author to offer principle improvements to the enforcement and improvement of legislation to bring it in line with the European Convention and the jurisprudence of the ECHR.

The author's research has shown that the proportion of crimes committed in Finland by foreign nationals and people without citizenship is constantly increasing. Additionally, The Finnish Immigration Service, the Administrative Court and the Supreme Court regularly consider cases of foreigners in Finland concerning residence permits, deportation, extradition or transfer to serve their sentences in the country of residence. The right to free assistance of an interpreter provided by Article 6 of the ECHR in relation to criminal proceedings. The author notes that the Constitution of Republic of Finland guarantees the right of everyone to conduct their case in court and other authorities by use of their language, Finnish or Swedish, as well as receive documents regarding the case drawn in that language as guaranteed by law.

${ }^{41}$ Case of Golder v. the United Kingdom, Strasbourg, 21 February 1975. http://hudoc.echr.coe.int/eng\#\{ "fulltext":["golder"],"documentcollectionid2":["GRAND CHAMBER","CHAMBER"],"itemid":["001-57496"]\} Viewed 2.5.2016.

42 Case of Airey v. Ireland. No. 6289/73. October 91979. http://hudoc.echr.coe.int/eng\#\{ "fulltext":["Airey\%20Ireland.\%20October\%209,\%20197 9."],"documentcollectionid2":["GRANDCHAMBER","CHAMBER"],"itemid":["001 57419"]\}.Viewed 4.5.2016.

${ }^{43}$ Case of Artico v. Italy, No 6694/74. May 13, 1980. http://hudoc.echr.coe.int/eng\#\{ "fulltext":["Artico\%20v.\%20Italy"],"documentcollectioni d2":["GRANDCHAMBER","CHAMBER"],"itemid":["001-57424"]\} Viewed 26.5. 2016. 
The Constitution guarantees the principle of equality before the law as stated in $\S 6$.

Violation of the individual's right to respect for private life, his home and his correspondence was repeatedly considered by the European Court of Human Rights. According to Article 8 of the European Convention, the Court has clarified the circumstances under which a state is permitted to violate this integrity and identified a number of requirements for the rules on wiretaps by the member countries of the Convention.

According to the European Court of Human Rights, the protection of privacy should be considered during both the telecommunication monitoring and the wiretapping. ${ }^{44}$

\section{Brief summary of Chapter 4}

ECHR has repeatedly voiced that in accordance with its established practice, clause 1 of article 6 guarantees judicial consideration of disputes relating to any individual's civil rights and obligations; this way the "right to trial" is implemented, it's most important aspect being the right of access to justice. However, this right would be illusory if the state's legal system let the final and binding judicial judgement remain inoperative to the detriment of one of the parties. It is hard to imagine that article 6 , while describing in detail the procedural guarantees to fair trial granted to the parties, would have left the realization of judicial judgements without protection; which would lead to situations incompatible with the principle of the supremacy of law.

As early as in 1979, ECHR declared and repeatedly voiced that the Convention is a living instrument, which must be interpreted in the light of current conditions. The author refers to the statement of the former ECHR President Jean-Paul Costa:

"The Court's case-law is not laid down once and for all... In other words, while observing the force of precedents, our Court applies the "stare decisis" rule flexibly; since its earliest judgments, moreover, it has treated the Convention as a living instrument which must be interpreted in the light of present-day conditions."

${ }^{44}$ Case of P.G. and J.H. v. The United Kingdom, para 42. No 44787/98. 25 September 2001.

http://hudoc.echr.coe.int/eng\#\{ "fulltext":["44787/98"],"documentcollectionid2":["GRA NDCHAMBER","CHAMBER"],"itemid":["001-59665"]\}.Viewed 4.7.2016. 
In view of the modern conditions, amendments to the Constitution of Latvia and Finland have been made, that secures and guarantees a broader scope of rights than those specified in the Convention and in the international human rights instruments. 


\section{CONCLUSION}

Roman justice formula justitia est fundamentum regnorum is the basis of the state and has become relevant in the XXI century. The indefeasible human rights and freedoms should not simply be recognized or officially declared but effective mechanisms to guarantee them should be created, including by means of international judicial organizations.

The conducted research shows a largest number of all the confirmed violations of articles of the Convention - is due to deviations from Article 6 of the Convention, which provides everyone a fair and public hearing within a reasonable time by an independent and impartial tribunal established by law. After the Convention entered into effect in Latvia on 1997, ECHR took 107 resolutions in respect of Latvia. In 94 passed resolutions, only in 13 cases the Court did not find violations of the European Convention or the articles of its protocols.

In 2014, ECHR ordered Latvia to pay 1,33 million Euros refund, of which Vistiņš alone was entitled to a 1,21 million Euros pay off.

In the period 1995-2015, ECHR admitted 151 violations of the Convention articles or its protocols by Finland, of which 98 cases constituted infringement of article 6 of the Convention, that is, $65 \%$.

Presented in this study is a comparative practice of case review in the Constitutional Court and in all three departments of Supreme Court of the Republic of Latvia with the procedural practices of the Supreme Court and Supreme Administrative Court of Finland suggest that earlier such comparative studies have not been conducted and that the conclusions drawn and approved proposals of the research, when implemented, can make a vital contribution to the protection of human rights in the Republic of Latvia and the Republic of Finland.

At the period of the author's work on the Doctoral thesis, major changes have affected some member states of the European Union and candidates for EU memberships. Consequent to Brexit vote in Great Britain, as well as the position of the Constitutional Courts of the member states of the Convention inevitably caused an increased trend of disagreements with separate decisions of the European Court of Human Rights, referring to the fundamental norms of the Constitution of the nation-state and have had an impact on interpretation of the issues raised in the research and on the final conclusion of the Doctoral thesis. 
Catastrophic terrorism faced by France, Belgium and Germany is pushing the EU member states towards taking drastic measures to preserve their security and stability; for example, France introduced a state of emergency. Following the coup d'étatattempt Turkey implemented a 3 months state of emergency - a state that aspires to join the EU. In this regard, the Finnish legal scholar Martin Scheinin recalled that the European Convention on Human Rights allows derogation from certain rights under extraordinary circumstances, but it does not allow non-compliance with all articles of the Convention. For example, the prohibition of torture, the death penalty and the prohibition of discrimination is one of the rights that must also be complied with in an emergency.

Similarly, there cannot be any derogation from the principle of punishment without law: No one shall be held guilty of any criminal offence on account of any act or omission which did not constitute a criminal offence under national or international law at the time when it was committed.

The challenges of the early 21 st century, faced by the individual states in the past, does not make other states exempt from their reoccurrence. However international law clearly states that even in an emergency, any person under the jurisdiction of EU member states retain the right to a fair hearing of his case in the court and has guaranties against torture, discrimination and death penalty.

The fight against terrorism is pushing European countries to take drastic measures to respect, protect and ensure the rights of the state to provide for the security of its citizens.

The author emphasizes that such measures should not restrict constitutional freedoms and respect for international law to a fair trial.

The above-mentioned circumstances have allowed the author to touch on the topic of the human rights situation in a rapidly changing situation in the EU, as well as helping to derive additional arguments in formulating of the conclusions and the nomination of individual proposals to improve the legislation in Latvia and Finland.

Emphasizing the role of the international law and in particular the European Convention, as expressed in the judgements of European Court of Human Rights, the author considers the protection of basic human rights and freedoms to be a paramount factor, as well as compliance with the requirements of fair judicial trial in accordance with the provisions of the Constitution, unless this results in mitigation or limitation of the fundamental rights provided by the 
Constitution or creates a threat for the democratic and constitutional foundations of the state.

In order to achieve the goals defined during the Doctoral thesis the following research objectives were set and solved:

1. The role and the legal significance of the Constitution in the national proceedings the Republic of Latvia and the Republic of Finland was analysed.

In the judgments of ECHR, particularly within the period 1979-2010, the Court repeatedly recommended that the national authorities, in particular courts, gave priority to the interpretation and enforcement of internal legislation and to judgements based on issues of constitutionality.

A different approach could result in diminution of the role of the Constitution as an act of supreme legal force valid on the territory of the country, and therefore - in undermining the foundations of the constitutional order and state sovereignty.

2. The place and role of the European Convention of Human Rights and practice of ECHR in a fair trial was defined.

The same basic values were laid down in the European Convention and the Constitution of Latvia and of Finland: the guarantee of the human and civil rights and freedoms - as integral components of the law-governed state, which contribute to effectuation of justice in the society. Most of the chapters in the Constitution of the Republic of Latvia and the Republic of Finland are close in wording and semantics to the Convention provisions.

Presented by the author is the analysis of judgements of the Latvian Constitutional Court and also the judgments of Supreme Court of Republic of Finland, which demonstrates its definite position regarding the fundamental value of the European system of protection of the rights and freedoms, expressed in consistent implementation of the Convention provisions and the judgments of the ECHR for the right to a fair trial.

3. The case review process in the Supreme Court of the Republic of Latvia and the Republic of Finland and the implementation of international standards of supervision of the judicial activities was investigated.

Considered in the study is a legal stance of the Supreme Court of Finland, suggesting the supremacy of the Constitution in implementation of the law and the supreme legal force of the Constitution of Finland in case of a conflict with international law. In the national legal order the Convention for the Protection of human rights and fundamental freedoms, together with the Court's practice, is only a guide for the interpretation of the fundamental rights and principles of the Constitution and only under the condition that this does 
not lead to a restriction or derogation of the fundamental rights of citizens guaranteed by the Constitution of the country.

4. The implementation and the right to protection of a fair trial was analysed.

The undertaken study has shown that despite the considerable differences between the national legal systems of the Republic of Latvia and the Republic of Finland, both systems use a statutory method of implementation of the international norms into their legal system, thus confirming the right to a fair trial.

Considering the decisions of the three departments of the Supreme Court of the Republic of Latvia and Supreme Court and Supreme Administrative Court of the Republic of Finland as an example, the author concludes that the practice of application of the European Convention and judicature of ECHR has seen a more frequent use by Republic of Latvia.

The author gives a comparative picture of the national judicature and the enforcement of ECHR judgements in the Republic of Latvia and in the Republic of Finland and puts forward some practical recommendations for discussion and approbation. 


\section{PRACTICAL RECOMMENDATIONS}

As shown in the undertaken research, the greatest number of violations by national courts involves the infringement of Article 6 of the Convention. Judicial errors in imposing sentences by national courts and the increasing number of cases considered by higher courts form the need to change the legislative procedure and make reforms in the judicial system.

After the comparative analysis of the European countries' Constitutions, the judgements of ECHR, the Constitutional Court of the Republic of Latvia and the Constitutional Courts of European countries, as well as the judgements of the Supreme Court of Latvia and of Finland, the author proposes the following changes to the Constitution of Republic of Latvia and the Republic of Finland:

1. The principle of the presumption of innocence is one of the basic principles of justice. The author proposes to make amendments to Article 8 of the Constitution of the Republic of Finland

and to present it as follows:

Everyone accused of committing a crime shall be considered innocent until his guilt is proven according to the rules fixed by law and confirmed by the sentence of a court, which has come into legal force.

The suspect or the accused is not obliged to prove his innocence.

Unremovable doubts about the guilt of a person shall be interpreted in favour of the accused.

2. The author proposes amendment of article 17 paragraph 2 of the Constitution of the Republic of Finland

and to present it as follows:

Everyone charged with a criminal offence has the rights to have the free assistance of an interpreter if he cannot understand or speak the language used in court and receive the legal documentations of the case in their native language.

3. The author proposes amending article 21 of the Constitution of the Republic of Finland

and to present it as follows:

In the determination of his civil rights and obligations or of any criminal charge against him, everyone is entitled to a fair and public hearing within a reasonable time by an independent and impartial tribunal established by law. 
Everyone has an entitlement, in accordance with the international treaties of the Republic of Finland to international bodies, for the protection of human rights and freedoms, if all available domestic remedies are exhausted, as generally recognized by rules of international law.

In case of unjustified infringement of rights, everyone is entitled to an appropriate remedy.

4. The author proposes to amend article 22 of the Constitution of the Republic of Finland

and to present it as follows:

Everyone is guaranteed the right to a qualified legal assistance. In cases stipulated by law, legal assistance is provided free of charge.

Everyone arrested, taken into custody or charged with a crime has the right to be assisted by a lawyer (defender) from the moment of arrest, detention or indictment.

5. The author proposes to amend article 74 of the Constitution of the Republic of Finland

and to present it as follows:

The duties of the Constitutional Commission include execution of reviews regarding constitutionality of bills and other matters brought for consideration, as well as conformity of bills with the norms of international conventions on human rights and conformity of resolutions of the European Court of Human Rights with the Constitution of Finland.

6. The most important element of a fair trial is the right of the accused to know the essence and nature of the charge against him. The author proposes to amend the $2 \S$ of Chapter 4 of the Procedural Code the Republic of Finland

and to present it as follows:

The accused has the right to use the free assistance of an interpreter at the stage of indictment, the preliminary investigation and in all stages of the proceedings.

7. The author proposes to amend paragraph 1 of Article 3 of Chapter 10 of the Coercive Measures Act of the Republic of Finland

and to present it as follows:

The investigative operations that limit the constitutional human and civil rights to privacy of correspondence, telephone conversations, postal, wire and other communications transmitted over the networks of electronic and postal services, as well as the right to privacy of home, are permitted only on the basis 
of a court judgement and collection of sufficient information on indicia of being-prepared, being-committed or committed grave crime.

8. The author proposes to amend Chapter 3, Article 30 of the Police Act and to present it as follows:

Coercive measures may be used, unless their application can be considered justified, taking into account the degree of the offense, the importance of the investigation and the extent of violated rights of the suspect or other persons, and only after obtaining a special permit issued by the court for a duration not exceeding one month.

9. In order to rectify the situation and to ensure the effective implementation of the rights of suspects and accused persons to legal aid, the author proposes to amend the Procedural Code of the Republic of Finland chapter $15 \S 1$ and for the Preliminary Investigation Law chapter $2 \S 1$ and bring them in line with Article 6 of the European Convention.

and to present it as follows:

Everyone charged with a crime has the rights to defend himself in person or through legal assistance of his own choosing or, if he has no sufficient means to pay for legal assistance, to be given it free when the interests of justice so require.

10. The author proposes to amend Article 6 of Chapter 2 of Law on Preliminary Investigation of Finland

and to present it as follows:

Everyone charged with a criminal offence to be guaranteed the right to qualified legal assistance. In cases stipulated by the law legal assistance is provided free of charge.

Any detained person held in custody and charged with a crime has the right to legal assistance (legal counsel) from the moment of detention, arrest or accusation.

A person suspected or charged with a criminal offence has the right to legal counsel at all stages of the criminal process.

11. The author proposes to amend article 89 of the Constitution of the Republic of Latvia

and to present it as follows:

The State recognizes and protects the fundamental human rights provided by Latvian Constitution as well as the laws and international treaties binding Latvia. 
The international statutes of human rights and the practice of their implementation at the level of constitutional law serve as means of interpretation making it possible to establish the substance and scope of basic rights and principles of the law-governed state, to the extent that such interpretation does not lead to mitigation or limitation of the fundamental rights contained in the Constitution.

12. The author proposes to amend article 92 of the Constitution of the Republic of Latvia

and to present it as follows:

Everyone may defend their rights and lawful interests in a fair court.

Every individual shall be presumed innocent unless his guilt is established by the law. In case of unjustified infringement of rights, everyone is entitled to the appropriate remedy.

Every individual has the right to assistance of an attorney selected by $\mathrm{him} / \mathrm{her}$ or, in case of insufficient means to pay for legal assistance, - to make use of appointed defence counsel free of charge, where it is required in the interests of justice.

13. The author proposes to amend article 96 of the Constitution of the Republic of Latvia

and to present it as follows:

Everyone shall have the right to the inviolability of his (her) private life, personal and family privacy, and protection of his (her) honour and good name.

Everyone shall have the right to privacy of correspondence, of telephone conversations and of postal, telegraph and other communications. This right may be limited only on the basis of a court order.

14. The author proposes to amend Article 2 of Chapter 4 Procedural Code of the Republic of Latvia

and to present it as follows:

Everyone arrested, taken into custody or charged with a crime has the right to a free assistance of an interpreter from the moment of arrest, detention or indictment, if he cannot understand or speak the language used in court.

15. The author proposes to amend Section 16 (Matters to be Adjudicated in the Constitutional Court) paragraph 6 of the Constitutional Court Law of the Republic of Latvia

and to present it as follows:

Conformity of Latvian national legal norms with those international agreements entered into by Latvia that is not in conflict with the Constitution. 
If the Constitutional Court comes to the conclusion that an ECHR ruling based on the Convention on Human Rights and Fundamental Freedoms interpreted contrary to the Latvian Constitution may not be enforced, the ruling shall be not enforceable, as concerns this provision.

16. The author proposes the following amendments to Article 1 of Chapter 88 Criminal Code of the Republic of Latvia

and to present it as follows:

1) use of explosives, arson, chemonuclear, chemical, biological, bacteriological, toxic or other weapons of mass destruction, mass poisonings, spreading of epidemics, epizootic (animal poisoning), kidnapping, hostagetaking, hijacking of air, land or water transport or other actions that have the purpose of intimidating a population, or aim to force the state, its agencies and international organizations to commit an act or refrain therefrom, or to harm the interests of the state, its people, or the interests of international organizations (terrorism), - shall be punished by life imprisonment or depravation of liberty for a term of nine to twenty years with confiscation of property or without confiscation of property and with supervision by a probation officer for up to three years.

17. The author proposes the following amendments and the supplementation to Article $88 .^{3}$ of the Criminal Code of the Republic of Latvia

and to present it as follows:

For a person who commits the recruitment and/or training of persons for the commitment of acts of terror, the applicable punishment is deprivation of liberty for a term from eight to fifteen years, with or without confiscation of property and with probationary supervision for a term of three years.

18. The author proposes to amend the Article 1 ( 5) of Chapter 34 (a) of Criminal Code of the Republic of Finland

and to present it as follows:

Deliberate infliction of grievous bodily harm, dangerous to human life, abduction and human trafficking, hostage-taking, arson, threat to health, theft or use of chemonuclear weapons as well as chemical, biological and bacteriological weapons - shall be punished by life imprisonment or depravation of liberty for a term from eight to twenty years with confiscation of property or without confiscation of property. 
The Doctoral thesis is a comprehensive completion of a research study. The purpose of the study and answers to formulated research questions have been achieved and supported by the answers of the ECHR Judges from Latvia and Finland and recognized experts in the field of international and constitutional law. 


\section{LIST OF REFERENCES AND OTHER SOURCES}

1. The Constitution of Republic of Latvia, Latvijas Republikas Satversme (19.06.2014. likuma redakcijā, kas stājas spēkā 22.07.2014)

2. The Constitution of Republic of Finland, 11 June 1999 (731/1999, amendments up to 1112 / 2011 included)

3. Universal Declaration of Human Rights, G.A. res. 217A (III), U.N. Doc A/810 at 71 (1948).

4. Convention for the Protection of Human Rights and Fundamental Freedoms, signed at Rome on 4 November 1950, as amended by Protocols Nos. 11 and 14, supplemented by Protocols Nos. 1, 4, 6, 7, 12 and 13 . http://www.echr.coe.int/Documents/Convention_ENG.pdf.

5. European Convention on Human Rights, as amended by Protocols 11 and 14. http://www.echr.coe.int/Documents/Convention_ENG.pdf

6. Council of the European Union. Luxembourg, 7 October 2013 , 14440/13 (OR.en) Presse 398

7. Resolution (95) 3 on Invitation to Latvia to Become a Member of the Council of Europe, adopted by the Committee of Ministers on 6 February 1995 at the 527th meeting of the Minister's Deputies.

8. The Conference on Security and Co-operation in Europe. Final Act, Helsinki, 1975.

9. Recommendation No.R(2000)2 of the Committee of Ministers to Member States on the Re-examination or Reopening of Certain Cases at Domestic Level Following Judgements of the European Court of Human Rights, adopted on 19 January 2000.

10. Vienna Declaration and Programme of Action, UN Doc. A/CONF.157/23.

11. Administrative Procedure Act. Hallintolaki. 434/2003.

12. Criminal Code of Finland. Rikoslaki. 39/1889

13. Criminal Procedure Act of Finland. Laki oikeudenkäynnistä rikosasioissa. $689 / 1997$

14. Code of Juriidical Procedure of Finland, Oikeudenkäymiskaari. 4/1734.

15. Krimināllikums. Latvijas Republikas likums ("LV", 199/200 (1260/1261), 08.07.1998.; Ziņotājs, 15, 04.08.1998.) [stājas spēkā 01.04.1999.] ar grozījumiem, kas spēkā uz 01.04.2013. Latvijas Vēstnesis. ("LV" 61(4867), 27.03.2013.).

16. Latvijas Republikas Satversmes komentāri; VIII nodaļa, Cilvēka pamattiesības, sagatavojis autoru kolektīvs R. Baloža vadībā, Latvijas Vēstnesis, 2011.

17. Human rights and the fight against terrorism. The Council of European Guidelines. Council of Europe Publishing March 2005. F-67075 Strasbourg Cedex.

18. Aulis Aarnio. Precedent in Finland. MacComick, Robert S.Summers. Aldershot/Dartmouth 1997.

19. Fredman M. Rikosasianajajan käsikirja. Talentum. Helsinki, 2013.

20. Grasis Jānis, Bojārs Juris. Necessity of the introduction of the progressive income tax system: A case of Latvia .ICESSIM 2015, Bali, Indonesia.

21. Hirvelä, Päivi - Heikkilä, Satu . Ihmisoikeudet - käsikirja EIT:n oikeuskäytäntöön. Edita Publishing Oy. Porvoo 2013. 934 p. 
22. Jacobs, White \&Ovey : The European Convention on Human Rights. Oxford University Press; 5 edition. 2010.

23. Jochen A. Frowein "The Transformation of Constitutional Law through the European Convention on Human Rights" in Dialogue Between Judges , European Court of Human Rights: Strasbourg, 2007.

24. Joksts O., Apsītis, A. 2013. The concept of infamy (infania) in Roman law. An engine for sustainable development and publicē security - the Roman exsample. Journal of Security and Sustainability Issues 3(1): 31 - 41, ISSN 20297017/ISSN 2029-7025 online.

25. Jundzis Tālavs. The World Economic Crises and Human Values. - The Internacional Conference ,Values and 21.st. Century” 19-21 November 2009, Podgorica, Montenegro. Podgorica 2010, pp.255.-265.

26. Jundzis Tālavs. The Baltic Way and restoration of independence: a success story with contemporary lessons. - 25 years after. The Baltic Way and the Collapse of Totalitarian Communism: European Memory and Political Inspiration. Transcript and materiāls of the international conference on 21-22 August 2015, Riga. Riga: Latvian Academy of Sciences Baltic Centre for Strategic Studies, 2015., pp.86.-91.

27. Krastiņš Uldis. Noziedzīgs nodarījums. Tiesu namu aǵentūra. 2000.

28. Kačevska Inga \& Rudevska Baiba. Practical Application of European Union Regulations Relating to European Union Level Procedure in Civil Cases: the Experience in Baltic States" (No. TM 2012/04/EK) Riga, Vilnus, Tallinn. 2012.

29. Kaija S. Aktuālākie transformācijas virzieni kriminālprocesa tiesību jomā Latvijā //Administratīvā un Kriminālā Justīcija, 2013, Nr.1, 15.-20. lpp.

30. Kaija S. Completion of Criminal Proceeding within a Reasonable Time in Latvia.// Jurisprudencija, ISSN 1392-6195 (print), ISSN 2029-2058 (online), 2013, 20(2), p. 733-756., EBSCO Publishing, Inc., International Index Copernicus, C.E.E.O.L. and ULRICH'S data bases.

31. Kazaka S. Kriminālprocesuālā aizturēšana un tiesības uz brīvību un drošību// Kriminālprocesuālās aizturēšanas tiesiskums. Zinātniski praktiskās konferences rakstu krājums. Rīga, LPA, 2008. 30.lpp.

32. Levits E. Judikatūra - pamati, problēmas, piemērošana // Latvijas Republikas Augstākās Tiesas Biḷetens. 2010. No 1.

33. Levits E. "Eiropas Cilvēktiesību konvencijas piemērošana Latvijas iestādēs un tiesās" ["The Application of the European Convention of Human Rights by public authorities and courts in Latvia"] in Ineta Ziemele (ed.) Cilvēktiesību isstenošana Latvijā: tiesa un administratīvais process [Implementation of Human Rights in Latvia: Judiciary and Administrative Procedure] Riga, Latvian Human Rights Institute, 1998.

34. Levits E. Par tiesiskās vienlīdzības principu//Latvijas Vēstnesis Nr.68, 2003.gada 8.maijā. 
35. Mits Mārtinšs. Komentāri Latvijas Republikas ievada ziṇojumam par Starptautiskā pakta "Par pilsoṇu un politiskajām tiesībām" izpildi Latvijā [Comments to the Initial Report of Latvia. Submitted by the Republic of Latvia as a party to the International Covenant on Civil and Political Rights], in: Cilvēktiesību Žurnāls [Latvian Human Rights Quarterly], Rìga, 1996.

36. Niemi Anne "Administratīvais process Somijā" ["Administrative Procedure in Finland"] in Ineta Ziemele (ed.) Cilvēktiesību īstenošana Latvijā: tiesa un administratīvais process [Implementation of Human Rights in Latvia: Judiciary and Administrative Procedure] Riga, Latvian Human Rights Institute, 1998.

37. Pellonpää Matti. Euroopan ihmisoikeussopimus. Talentum. 2005. 647 s.

38. Pellonpää Matti, Gullansin Monica, Pölönen Pasi, Tapani Antti. Euroopan ihmisoikeusssopimus. Talentum. 2012. 1008 p.

39. Rezevska D. Judikatūra kā tiesību avots: izpratne un pielietošana // Latvijas Republikas Augstākās Tiesas Biḷetens. 2010. No 1.

40. Scheinin Martin. International Human Rights Norms in the Nordic and Baltic Countries. Dordrecht 1995: Kluwer Law International. 309 pp. ISBN 90-4110153-5.

41. Tapanila Antti. Epäillyn oikeudet ja hyödyntämiskielto hovioikeuksissa. Defensor Legis, 2014

42. Torgāns Kalvis. Eiropas Jurisprudences vērtības civiltiesībās: pārṇemt vai nogaidīt. Jurista Vārds, 20.11.2007., Nr. 47 (500)

43. Ušacka Anita. Building the International Criminal Court”), Pacific McGeorge Global Buisness \& Development Law Journal, vol. 23, no. 2 (2011), p. 225-242.

44. Viljanen Jukka. The European Convention on Human Rights and the Tranformation of the Finnish Fundamental Rights System: The Model of Interpretative Harmonosation and Interaction. Scandinavian Studies in Law. 1999-2012.

45. Vilks Andrejs. Krimināltiesiskā politika: diskursa analīze un attīstības perspektīvas. Monogrāfija.Rīga,"Drukātava", 2013, ISBN 978-9984-853-83-3, 243 lpp.

46. Ziemele Ineta and Liede Lāsma. Reservations ti Human Rights Treaties: from Draft Guideline 3.1.12 to Guideline 3.1.5.6. NYU School of Law, New York, 2012.

47. Ziemele, Ineta. Special Rapporteur of the International Law Commision. CAHDI. The Judge and International custom. Paris, 21 Septembrer 2012.

48. Вильдхабер Л. Роль и значение прецедента в деятельности Европейского Суда по правам человека // Право и политика. Москва. 2001. №8.

49. Кашепов В.П. Международно-правовые стандарты в уголовной юстиции Российской Федерации. “Анкил”. Москва. 2012.

50. К Ковлер А.И., отв. ред.: Гулиев В.Е.Исторические формы демократии: проблемы политико-правовой теории. Москва. Наука. 1990.

51. Осминин Б.И. Заключение и имплементация международных договоров и внутригосударственное право. Инфотропик Медиа. Москва. 2010.

52. Руднев В.И. "Глава Европейский суд по правам человека и его влияние на изменение законодательства о судопроизводстве.” Международноправовые стандарты в уголовной юстиции Российской Федерации. “Анкил”. Москва. 2012. 


\section{Cases in European Court of Human Rights}

53. Case of Golder against the United Kingdom, No 4451/70. 21 February 1975.

54. Case of Wiggins v. the United Kingdom, 1978, No 7456/76, 8 February 1978.

55. Case of Marckx v. Belgium, No 6833/74. 13 June 1979

56. Case of Airey v. Ireland . No 6289/73, 9 October 1979.

57. Case of Artico v. Italy. No 6694/74 , 13 May 1980.

58. Case of Salesi v. Italy. No 13023/87, 26 February 1993.

59. Case of Hornsby v. Greece, No 18357/91. 19 March 1997.

60. Case of Brumărescu v. Romania, No 28342/95, 28 October 1999.

61. Case of P.G. and J.H. v. the United Kingdom, September 2001. No 44787/98, 25 September 2001.

62. Case of Fogarty v. the United Kingdom. No 37112/97. 21 November 2001.

63. Case of Ryabykh v. Russia, Application № 52854/99, 24 June 2003.

64. Case of Bosphorus Hava Yolları Turizm ve Ticaret Anonim Şirketi v. Ireland, No 45036/98, 30 June 2005.

65. Case of Malininas v. Lithuania, No 1007/04, 1 July 2008.

66. Case of Edwards and Lewis v. the United Kingdom.

67. Case of Sequeira v. Portugal, No 18545/06, 20 October 2009.

68. Case of Pyrgiotakis v. Grece, No 15100/06, 21 February 2008

69. Case of Teixeira de Castro v. Portugal, No 44/1997/828/1034, 9 June 1998.

70. Case of Vanyan v. Russia, No 53203/99, 15 December 2005.

71. Case of Ramanauskas v. Lithuania, No 74420/01, 5 February 2008.

72. Case of Tre Traktorer AB v. Sweden, No 10873/84, 7 July 1989.

73. Case of Mellacher and Others v.Austria, No 10522/83; 11011/84; 11070/84. 19 December 1989.

74. Case of Henrik Urban and Ryszard Urban v. Poland. No 23614/08. 30 November 2010.

75. Case of Verein Gegen Tierfabriken Schweiz (VGT) v. Switzerland, No $32772 / 02$.

\section{Cases v. Finland in ECHR}

76. Case Kari Uoti v. Finland, No 61222/00, 9 April 2007.

77. Case Jussi Uoti v.Finland, No 20388/02, 23 October 2007.

78. Case of Mild and Virtanen v. Finland. Nos 39481/98 and 40227/98.

79. Case of Mariapori v.Finland, No 37751/07) final 06.10.2010.

80. Case of Marttinen v. Finland. No 19235/03. 21.04.2009.

81. Case of Jussila v. Finland. No 73053/01. 23 November 2006.

82. Case of Glantz v.Finland . No 37394/11. 20 May 2014.

83. Case of Nykänen v.Finland, No 11828/11 20 May 2014.

84. Case of Häkkä v. Finland, No 758/11, 20 May 2014.

85. Case of Kangasluoma v. Finland, No 48339/99 , January 20, 2004.

86. Case of Selistö v. Finland, November 16, 2004 , No 56767 /00 . 


\section{Cases v. Latvia in ECHR}

87. Case of Lavents v. Latvia, No 58442/00, 28 November 2002.

88. Case of Slivenko v. Latvia, Application No 48321/99, 9 October 2003.

89. Case of Ždanoka v. Latvia, No 58278/00, 16 March 2006.

90. Case of Bazjaks v. Latvia. No 71572/01. 19 October 2010.

91. Case of Marina v. Latvia. 26 October 2010.

92. Case of Birznieks v. Latvia, No 65025/01, 31 May 2011.

93. Case of Černikovs v. Latvia, No 71071/01, 31 May 2011.

94. Case of Ternovskis v. Latvia, No 33637/02) 29 April 2014.

95. Case of Yelverton Investments B.V. and others v. Latvia, 18 November 2014.

96. Case of Čalovskis v. Latvia. No 22205/13. 24 July 2014.

97. Case of Liepinš v. Latvia, No 31855/03. 25 November 2014.

98. Case of Meimanis v. Latvia. No 70597/11. 21 July 2015.

99. Case of Balajevs v. Latvia, No 8247/07, 8 April 2016.

\section{Court of Justice of the European Union}

100. C-37/98, Savas, ECLI:EU:C:2000:224

101. C-619/10 Trade Agency Ltd v Seramico Investments Ltd

102. C-7/98 Krombach.

103. C-420/07 Apostolides.

104. C-38/98 Renault.

105. C391/95 Van Uden.

106. C-104/03 Ste Paul Dairy Industries.

\section{The judgments of Italian Constitutional Court, Constitutional Court of Austria, German Federative Constitutional Court}

107. Italian Constitutional Court, 19 November 2012 , No 264/2012.

108. Italian Constitutional Court, June 27, 1996 , Venezia v.Ministero di Grazia e Giustizia. Judgment No.223. Rivista di Diritto Internazionale 815. (1996)

109. Constitutional Court of Austria, 14 October 1987 , N B267/86

110. German Federative Constitutional Court October 14, 2004, 2BVR 1481/04

\section{Decisions of the Constitutional Court of the Republic of Latvia}

111. 2014.gada 28.novembra Latvijas Republikas Satversmes tiesas nolēmums Nr. 2014-09-01.

112. 2015.gada 12.februāra Latvijas Republikas Satversmes tiesas nolēmums Nr. 2014-08-03.

113. 2013.gada 14.maija Latvijas Republikas Satversmes tiesas nolēmums Nr. 2012-13-01.

114. 2010.gada 20.decembra Latvijas Republikas Satversmes tiesas nolēmums Nr. 2010-44-01. 
115. 2010.gada 7.oktobra Latvijas Republikas Satversmes tiesas nolēmums Nr. 2010-01-01.

116. 2011.gada 19.oktobra Latvijas Republikas Satversmes tiesas nolēmums Nr. 2010-71-01.

117. 2009.gada 3.jūnija Latvijas Republikas Satversmes tiesas nolēmums Nr. 2008-43-0106.

118. 2009.gada 7.aprīla Latvijas Republikas Satversmes tiesas nolēmums Nr. 2008-35-01.

119. 2007.gada 18.oktobra Latvijas Republikas Satversmes tiesas nolēmums Nr. 2007-03-01.

120. 2005.gada 14.septembra Latvijas Republikas Satversmes tiesas nolēmums Nr. 2005-02-0106.

121. 2005.gada 13.maija Latvijas Republikas Satversmes tiesas nolēmums Nr. 2004-18-0106.

122. 2010.gada 4.janvāra Latvijas Republikas Satversmes tiesas nolēmums Nr. 2004-16-01.

123. 2003.gada 5.jūnija Latvijas Republikas Satversmes tiesas nolēmums Nr. 2003-02-0106.

124. 2002.gada 22.oktobra Latvijas Republikas Satversmes tiesas nolēmums Nr. 2002-04-03.

125. 2002.gada 22.februāra Latvijas Republikas Satversmes tiesas nolēmums Nr. 2001-06-02.

126. 2000.gada 30.augusta Latvijas Republikas Satversmes tiesas nolēmums Nr. 2000-03-01.

\section{Decisions of the Departament of Criminal Cases of Supreme Court of the Republic of Latvia}

127. 2015.gada 20.augusta nolēmums lietā Nr. SKK $-279 / 2015$.

128. 2015.gada 7.augusta nolēmums lietā Nr. SKK -303/2015.

129. 2015.gada 11.jūnija nolēmums lietā Nr. SKK -133/2015.

130. 2015. gada 28.aprīḷa nolēmums lietā Nr. SKK -46/2015.

131. 2015.gada 10.februāra nolēmums lietā Nr. SKK -5/2015.

Decisions of Departament of Civil Cases of Supreme Court of the Republic of Latvia

132. 2015.gada 20.maija nolēmums lietā Nr. SKC-2344/2015.

133. 2015. gada 13.maija nolēmums lietā Nr. SKC-1427/2015.

134. 2015.gada 27.februāra nolēmums lietā Nr. SKC-41/2015.

135. 2015.gada 25.februāra nolēmums lietā Nr. SKC-1/2015. 
Decisions of the Departament of Administrative Cases of Supreme Court of the Republic of Latvia

136. 2015.gada 25.jūnija nolēmums lietā Nr. SKA-864-15.

137. 2015.gada 8.jūnija nolēmums lietā Nr.A43016313 SKA - 642/2015.

138. 2015.gada 29.maija nolēmums lietā Nr.A420527613 SKA-237-15.

139. 2015.gada 6.maija nolēmums lietā Nr.A420412811 SKA-241-15.

\section{Supreme Court of the Republic of Finland}

140. KKO:1990:93. Judgment on 10.7.1990.

141. KKO:1991:84. R90/770. Judgment on 6.6.1991.

142. KKO:2008:24 . Judgment on 14.3.2008.

143. KKO:2009:27. Judgment on 17.4.2009.

144. KKO:2009:80, Judgment on 20.10.2009.

145. KKO:2014:35. Judgment on 28.5.2014. 


\section{ACKNOWLEDGEMENTS}

I would like to acknowledge Professor Vitolds Zahars for his supervision of my doctoral study and Doctoral thesis writing, always found a time for comments that raised the quality of my study.

I would like to express sincere gratitude to the Dean of Faculty of Law, Rìga Stradiņš University, Professor Andrejs Vilks and the Chief of Doctoral studies programme "Law Sciences" Professor Osvalds Joksts for encouragement and support during my work on the Doctoral thesis.

I am very grateful for the answers provided by Mārtinšs Mits, Gunārs Kūtris, Aivars Endziņ̌s, Uldis Ķinis, Juris Jelāgins, Pauliine Koskelo and the staff of chancery of the Supreme Court of the Republic of Finland.

I would like to take this opportunity to express my deep gratitude and appreciation to all the individuals, not only for contributing to the substance of my research but also morale support and guidance.

The Professors and Members of the Faculty of Law at the Rīga Stradiñš University have always been friendly and willing to assist whenever such a need arose.

I also want to express my appreciation of everyone who has supported and encouraged me throughout my studies in Latvia and also in Finland, especially the lawyer Kari Korhonen from law office Kari Korhonen Oy.

I am sincerely grateful to my family for understanding and support provided during the research and writing of my Doctoral Thesis. 